\title{
LATE HOLOCENE EVOLUTION OF THE NORTHEAST INTERTIDAL REGION OF SEPETIBA BAY, RIO DE JANEIRO (BRAZIL)
}

\author{
Anita Fernandes Souza Pinto ${ }^{1}$, Maria Virgínia Alves Martins ${ }^{2,3}, *$, Maria Antonieta da Conceição \\ Rodrigues ${ }^{2}$, Leandro Nogueira ${ }^{1}$, LAZAro Luiz Mattos LaUT ${ }^{4}$, Egberto Pereira
}

1 Programa de Pós-graduação em Análises de Bacias e Faixas Móveis, Faculdade de Geologia, Departamento de Estratigrafia e Paleontologia, Rua São Francisco Xavier, 524, 20.550-900, Maracanã, Rio de Janeiro, RJ, Brazil. anitafspinto@gmail.com, leandronogueira5@gmail.com 2 Universidade do Estado do Rio de Janeiro - UERJ, Faculdade de Geologia, Departamento de Paleontologia e Estratigrafia, Av. São Francisco Xavier, 524, 20550-013, sala 2020, Maracanã, Rio de Janeiro, RJ, Brazil. virginia.martins@ua.pt, tutucauerj@gmail.com, egbertogeologia@gmail.com

3 Universidade de Aveiro, Departamento de Geociências, GeoBioTec, Campus de Santiago, 3810-193, Aveiro, Portugal

4 Laboratório de Micropaleontologia - LabMicro, Departamento de Ciências Naturais, Universidade Federal do Estado do Rio de Janeiro UNIRIO, Av. Pasteur, 458, 22.240-490, IBIO/CCET, sala 500, Urca, Rio de Janeiro, Brazil. lazarolaut@hotmail.com

*Corresponding AUTHOR, virginia.martins@ua.pt

Received on 28 December 2015

Received in revised form on 02 March 2016

Accepted on 06 March 2016

Editor:

Fernando Joaquim Tavares Rocha, Universidade de Aveiro, Portugal
Citation:

Pinto, A.F.S., Martins, M.V.A., Rodrigues, M.A.C., Nogueira, L., Laut, L.L.M., Pereira, E., 2016. Late Holocene evolution of the Northeast intertidal region of Sepetiba Bay, Rio de Janeiro (Brazil). Journal of Sedimentary Environments, 1(1): 107-138.

\section{Abstract}

This work is based on the study of the core T1 collected in the Guaratiba Mangrove, located on the northeastern margin of Sepetiba Bay. Few studies dealing with the application of benthic foraminifera to study sea level changes during the Holocene have been conducted in Sepetiba Bay, State of Rio de Janeiro, Brazil. In order to fill this gap, the core T1 was studied using textural, geochemical (carbonate, total organic carbon, total sulfur and stable isotopes evaluated in Ammonia tepida) and microfaunal (benthic foraminifera) data, unveiling paleoecological relationships of these organisms and the evolutionary scenario of Guaratiba Mangrove.

Radiocarbon results indicate an estimated age of about 2400 yrs cal BP for the core base. Textural, geochemical and benthic foraminifera data suggest that the study area changed significantly during the last $2400 \mathrm{yrs}$ cal BP. It experienced

\section{Introduction}

Sea level changes over geological time occurred in very different time and space scales (Milne et al., 2009; Church et al., 2010). Such modifications consist of the temporary result of complex interactions between continental surface and sea (Suguio, 1999; Church et al., 2011). Volume changes coastal waves action and shoreface processes in the period between $\approx 2.400-1.400 \mathrm{yrs}$ cal BP; then, this phase gave place to a shallow marine environment similar to that found currently in internal and protected areas of Sepetiba Bay, between $\approx 1.400-350$ yrs cal BP. Thenceforth, the study area evolved to the present mangrove environment. Factors related to climatic oscillations and the formation, evolution and events of rupture of Marambaia sand ridge influenced the late Holocene evolution of the northeast intertidal area of Sepetiba Bay.

Keywords: Foraminifera. Stable isotope. Late Holocene. Guaratiba Mangrove. Environmental Evolution

of ocean basins (tectono-eustasy) and variations in volume of water in the oceans (glacioeustasy) cause effects on a global scale (IPCC, 2014). On the other hand, alterations of the continents elevation (tectonics and isostasy) and modifications in the geoid form (geoidal eustasy) operate in local or regional scales (IPCC, 2014). 
The reconstruction of ancient sea levels is directly related to the determination of indicators that can provide the relative position of the past mean sea level, or paleo shoreline, at a certain place and a certain period (Suguio et al., 2005). The indicators of sea level change can be grouped into three main categories: i) geological records, such as geomorphological features related to marine terraces, marine abrasion, beach rocks, paleo beach ridges, among others; ii) biological records, represented by animal and marine plant remains, fossils and microfossils and paleo mangroves and; iii) pre-historical and archaeological records (Martin et al., 1997). More recently, other indicators have been incorporated, such as records of tide gauges and series of satellite radar altimeters, which are contributing to estimate the global mean sea level in short temporal scales.

The marine terraces are deposits of coastal sediments characterized by topographical levels related to sea level fluctuations. According to Suguio et al. (2005), marine terraces are examples of paleo sea levels above the current. The marine abrasion terraces represent erosional surfaces on older basement rocks. These erosional features arising from the wave action above the current sea level, are also indications of past sea level oscillations. For Bhatt and Bhonde (2006), marine notches are concave cavities created on the rocky shores and cliffs by wave action. In the coastal plain of Rio Grande do Sul, for example, the sea level rise due to the last deglaciation gave way to the barrier island system (Suguio and Martin, 1978).

Biological indicators - for example, carbonized tree trunks, urchin marks, mollusk remains, paleo barnacles have indicated sudden changes of sea level in the landscape along the Brazilian coast (Angulo, 1993; Angulo and Suguio, 1995; Angulo and Lessa, 1997; Angulo et al., 1999; Andrade and Dominguez, 2003; Fernandes et al., 2002).

Urchin marks are important indicators of sea level variations, since such perforations are found in the intertidal areas (Fernandes et al., 2002). Such information is very important for the regional understanding of possible sea level oscillations, particularly those that occurred during the Quaternary.

Considering the occurrence and state of preservation, bivalve shells are seen to be good indicators of sea level changes. According to Angulo (1993), the species Anomalocardia flexuosa (Linnaeus, 1767), refereed as Anomalocardia brasiliana (Gmelin, 1791), lives below the low tide level to a few meters deep. When there is no much reworking by other organisms, these shells banks serve to indicate at least the low tide level at the period in which these bivalves lived. Based on these criteria and knowing the range of the paleo tide in the area, these indicators can unveil the paleo sea level.

Paleo barnacles have also been useful in studies on sea level changes during the Holocene. Barnacles are crustaceans that live in the intertidal zone of rocky shores environments. Marks left on the rocks by paleo barnacles can be windows onto estimating the sea level change (Pirazzoli et al., 1985).

Vermetid are gastropods with tube-shaped shells that live attached to bedrocks. The genera Petaloconchus Lea, 1843 and Dendropoma Mörch, 1861 are the most common on the Brazilian coast. Angulo et al. (1999) developed a variation curve of sea level for the coast of Paraná State using the species Petaloconchus varians (d'Orbigny, 1839). According to Laborel (1986), the accuracy in the evaluation of sea level range from vermetids can range from $+0.1 \mathrm{~m}$ and $+1.0 \mathrm{~m}$, depending on the exposure to waves and amplitude of the tides.

Benthic foraminifera provide excellent paleoecological and paleoenvironmental proxies which can be applied to studies of sea level rise (e.g. Leckie and Olson, 2003; Carson et al., 2008; Li et al., 2013; Romahn et al., 2015). Thus, their faunal assemblages shed light on the environmental evolution along a time scale and provide important parameters for the identification of Holocene sea-level change (Horton et al., 2007; Strachan et al., 2014).

\subsection{Holocene studies of sea level change in Brazil}

In the coastal region of Brazil, notable evidences of the alteration of the shoreline position and in the sea level changes during the Holocene are known (Suguio and Martin, 1978). There are many studies dealing with the variations of mean sea level, during the Holocene. They were based on sedimentary/stratigraphic, geomorphological and paleontological records in Brazilian coastal areas (Castro et al., 2014 and references herein). Fluctuations in the sea level during the Holocene were important in the construction and evolution of Brazilian coastal plains (Martin et al., 1997). Factors influencing the evolution of these coastal plains were investigated by for instance Roncarati and Neves (1976), Martin et al. (1984, 1985), Suguio and Tessler (1984), Flexor et al. (1984), Suguio et al. (1985), Villwock (1994), Angulo and Lessa (1997), Turcq et al. (1999), Suguio (1999, 2003a, b) and Castro and Suguio (2010).

These studies improved the knowledge on ancient sea levels, as well as they proposed models and curves of variation of mean sea level for certain coastal regions (e.g. 
Angulo and Suguio, 1995; Angulo and Lessa, 1997; Martin et al., 1997; Angulo et al., 1999; Castro et al., 2009).

However, the used evidences do not always show very accurately the height reached by sea level. There are records that indicate that the sea level rose during the Holocene for 3 to $4 \mathrm{~m}$ above the current in northeastern Brazil coast (e.g., Suguio et al., 1985; Martin et al., 1986; Bezerra et al., 2003), while other studies indicate increases of less than $1 \mathrm{~m}$ for the same period (e.g., Angulo and Lessa 1997; Lessa and Angulo 1998; Angulo et al., 2006).

Differences in sea level detected among several locations in Brazil have been related to the influence of tectonics (Martin et al., 1986; Angulo and Suguio, 1995). In fact, an increasing number of studies have demonstrated the significance of tectonics in the development of sedimentary Quaternary successions in Brazil (Bezerra and Vita-Finzi, 2000; Costa et al., 2001; Bezerra et al., 2003; Rossetti et al., 2008 a, b). Some studies have also suggested that episodes of eustatic increases along the South American plate during the Quaternary, were reinforced by subsidence due to postrifting tectonic reactivations (Moraes-Neto and Alkmin, 2001; Bezerra et al., 2001; Barreto et al., 2002).

Moreover, despite the significant volume of studies focusing on the Holocene sea level changes, this remains a topic of great debate. No consensus even on the magnitude of the fluctuations or on the chronology of transgressiveregressive events was still reached. So the reconstruction of the history of sea level along the Brazilian coast is a matter still under consideration.

\subsection{The main goal of this study}

This work aims to contribute for the knowledge of sea level influence at the SE Brazilian coastal area during the late Holocene. It analyses textural, geochemical (TOC, sulfur, $\mathrm{CaCO}_{3}$ and stable isotopes data) and microfaunal (benthic foraminifera) data along the core T1 (480 cm long). This core was collected at the northeast region of Sepetiba Bay, in the Guaratiba Mangrove (State of Rio de Janeiro coast). Thus, this study aims to reconstruct the paleoenvironmental evolution of Guaratiba Mangrove in the last $\approx 2400 \mathrm{yrs}$ cal BP.

Only a small number of works aiming to study the ecology of benthic foraminifera were performed in the Guaratiba Mangrove. Zaninetti et al. $(1976,1977)$ conducted the first ecological study based on foraminifera in this area.
These authors partitioned the mangrove into five regions, based on the diversity index of Fisher et al. (1943).

Brönnimann et al. (1981 a, b) using environmental parameters (e.g. pH, salinity, temperature and suspended material) studied several stations in tidal channels. These authors verified that species of the order Textulariida dominate the benthic foraminifera assemblages in those environments.

Laut et al. (2006, 2009, 2012) and Laut and Rodrigues (2011) established different faunal assemblages in the study area through studies of samples collected in channels and in Guaratiba Mangrove and Sepetiba Bay. These authors proposed a new division of Guaratiba Mangrove.

\subsection{Study area}

The Guaratiba Mangrove is situated in the northeastern region of Sepetiba Bay (southeastern Brazil coast, State of Rio de Janeiro). Mangroves are transitional ecosystems between the marine and terrestrial environments, developed on low energy intertidal zones, at sub-tropical and tropical regions (Pereira et al., 2007).

The study area is part of the Guaratiba/Sepetiba coastal complex and is bordered by the latitudes $23^{\circ} 00^{\prime} \mathrm{S}-23^{\circ} 03^{\prime} \mathrm{S}$ and longitudes $43^{\circ} 40^{\prime} \mathrm{W}-43^{\circ} 37^{\prime} \mathrm{W}$. It is situated between the mouths of Piraquê and Piracão rivers (Figure 1). However, several other rivers flow to Sepetiba Bay such as the Guandu, Flecha and Guarda rivers.

Vast areas of Guaratiba Mangrove substrate consist of sandy sediments with abundant plant and animals (mainly mollusks and crustaceans) debris (Pereira et al., 2007, 2009). This environment should correspond to a transgressive sedimentary sequence related to the sea level rise since the last glaciation (Figueiredo Jr. et al., 1989).

The lithology around the Sepetiba Bay is essentially composed by Neoproterozoic rocks with intrusions of alkaline Cenozoic rocks and Quaternary sediments of fluvialmarine origin scattered throughout the area (SEMA, ZEERJ, 1996). Among the Neoproterozoic units there are tonalite, granodiorite, granite and foliated gabbro associated with the Rio Negro Complex (Tupinambá et al., 2000; Heilbron and Machado, 2003) and the Turvo River Granitoid (Machado et al., 1996). The rivers that flow toward Sepetiba Bay cross these rocks and discharge sediments resultant of the erosion of the aforementioned rocks in these coastal systems. 


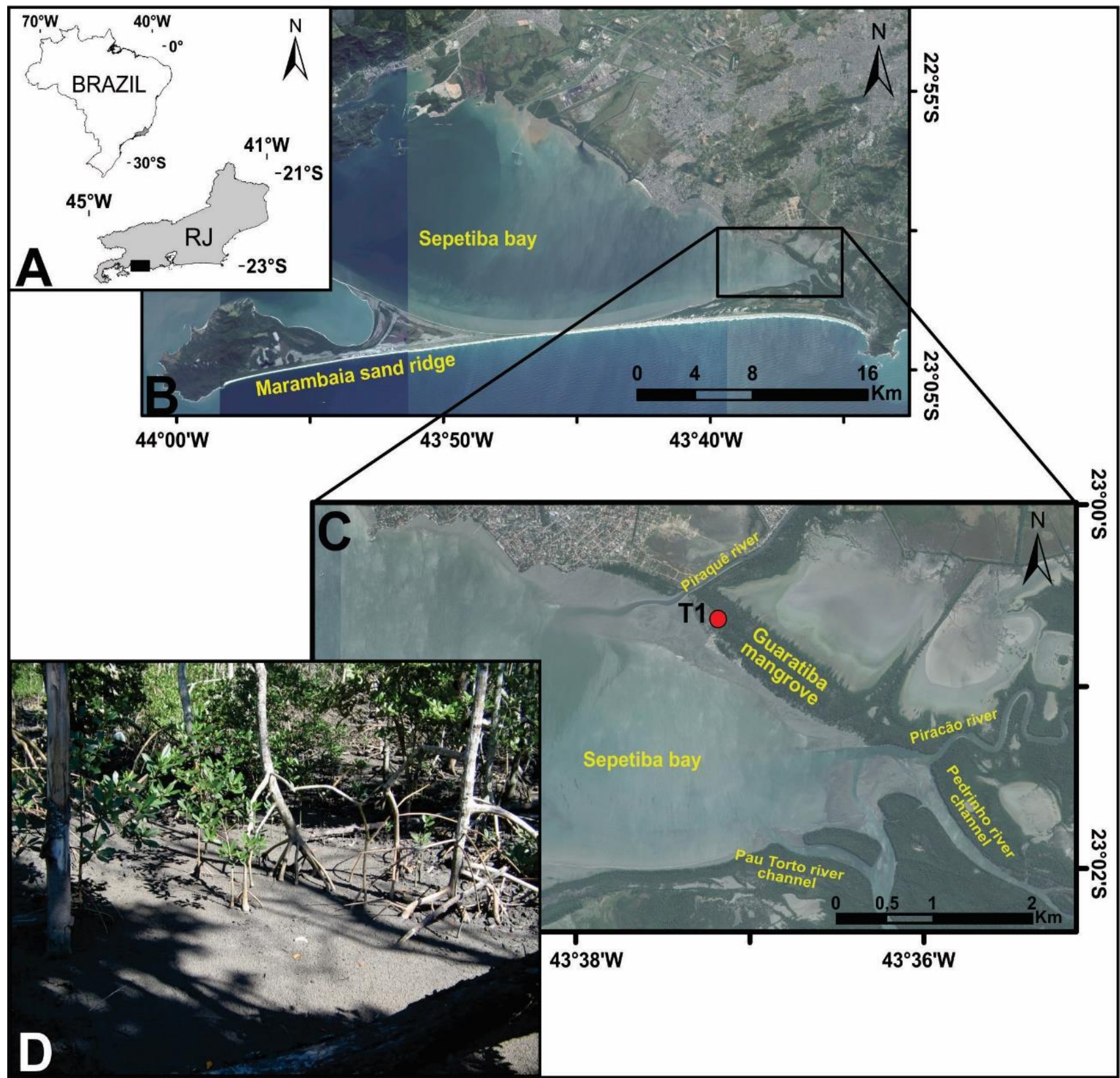

Fig. 1. A: Localization of Sepetiba Bay in the State of Rio de Janeiro (Brazil); B: Sepetiba Bay, Marambaia sand ridge and the Guaratiba tidal plain/mangrove (highlighted by the retangle with black contourn); C: Place of core T1 sampling; D: General aspects (soil, vegetation) of the sampling site.

\section{MATERIALS AND METHODS}

\subsection{Core sampling}

This work analyzes the sediments obtained along the core

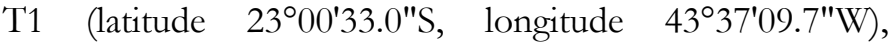
collected in the tidal plain of Guaratiba mangrove during low tidal conditions (Figure 2). For coring was used a Russian corer, a manual use sampler that allows the collection of successive sections of $50 \mathrm{~cm}$. It was possible to acquire a core with $490 \mathrm{~cm}$, divided into nine sections of $50 \mathrm{~cm}$. However, considering that among each section there was loss of sediment (the length of the sampler probe), the recovered sedimentary column reached in fact $480 \mathrm{~cm}$. 


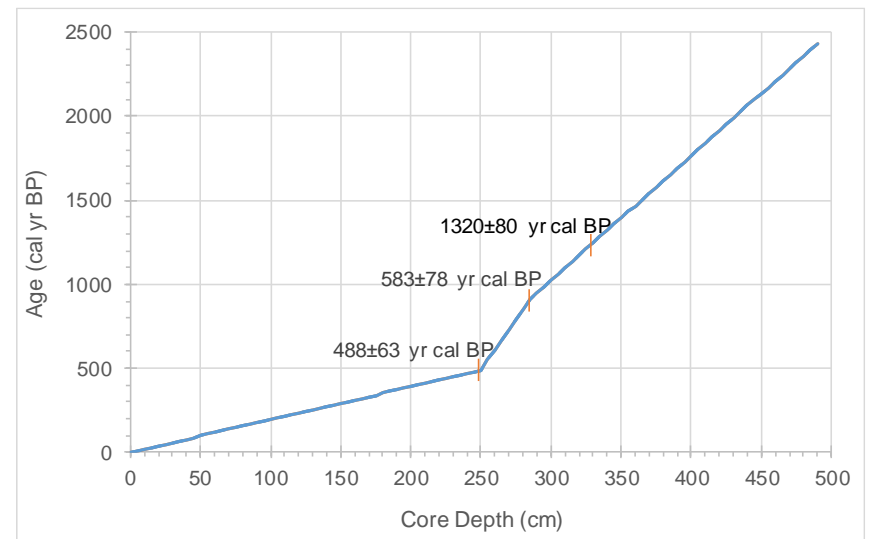

Fig. 2. Age model for core T1, obtained by linear interpolation of radiocarbon data (presented in this plot) along the core.

Each section was wrapped in plastic wrap to prevent drying and unpacked in Micropaleontology Laboratory of Universidade do Estado do Rio de Janeiro (UERJ). The core was then photographed, macroscopically described (color, texture, sedimentary structures and biogenic content) and sub-sampled in $5 \mathrm{~cm}$ intervals at each $10 \mathrm{~cm}$. The sediments of each interval was subdivided for subsequent geochemical, particle size and foraminifera analyses.

\subsection{Geochemical and textural analyzes}

The samples for particle size analysis were weighted and divided into two parts: $>1.4 \mathrm{~mm}$ and $<1.4 \mathrm{~mm}$ by screening. The sediment fraction $<1.4 \mathrm{~mm}$ was submitted to analysis in the laser granulometer MasterSizer2000 mode, at Laboratory of Geological Oceanography of UERJ. This equipment uses the laser diffraction answer for determining particle sizes. The textural classification of sediments was based on Folk and Ward (Folk and Ward, 1957).

About $250 \mathrm{mg}$ of each sample was submitted to total organic carbon (TOC) and total sulfur (S) analyses in the Laboratory of Chemostratigraphy and Organic Geochemistry (LGQM-UERJ), with the LECO SC-444 analyzer, which directly provided the percentage of TOC and S.

\subsection{Radiocarbon dating}

Mollusk shells recovered from three layers were used for radiocarbon dating. The radiocarbon analyses were performed in the Beta Analytics laboratory (Miami, Florida). This work uses the 2-sigma calibrated before present (BP) ages, based on Marine 13 database (Reimer et al., 2013; Talma and Vogel, 1993).

\subsection{Foraminifera}

The samples were spited in aliquots of $10 \mathrm{ml}$ of sediment. The sediment fraction $500-63 \mu \mathrm{m}$ was separated by wet sieving according to the methodology described by Schröder et al. (1987). The sediments fractions $>500 \mu \mathrm{m}$ and $<63 \mu \mathrm{m}$ were discarded.

After washing, the samples were dried in an oven at $\approx 50^{\circ} \mathrm{C}$. In the dry material was added Trichloroethylene $\left(\mathrm{C}_{2} \mathrm{HCl}_{3}\right)$, which resulted in the separation of foraminifera tests by flotation, due to their lower density than most part of terrigenous particles (Scott et al., 2001). The supernatant material was recovered in a filter paper. Foraminiferal tests were separated from the sediment, identified and counted under a binocular microscope and fixed in microslides (Uehara et al., 2007). All the specimens found were identified and counted in each sample $(10 \mathrm{ml})$. So foraminifera density is the number of specimens per species per $10 \mathrm{ml}$ of sediment. The species richness (the number of species) was determined for each sample.

The species identification was based on several references, such as Cushman and Brönnimmann (1948 a, b), Tinoco (1965), Loeblich and Tappan (1988), Debenay et al. (1998), Semensatto-Jr. and Dias-Brito (2004), Murray (2006) and Laut et al. (2012). The suprageneric classification follows the World Register of Marine Species (WoRMS: http://www.marinespecies.org/index.php; accessed on 03.01.2016).

\subsection{Carbon and oxygen isotopes $\left(\delta^{13} \mathrm{C}\right.$ and $\left.\delta^{18} \mathrm{O}\right)$}

The stable isotopes were obtained in 10 to 15 specimens of Ammonia tepida. Data were held in LGQM-UERJ. Ammonia tepida was chosen since it is the most common calcareous species along the core and in the study area (Brönnimmann et al., 1981 a, b).

The specimens for isotopic analysis were first washed in ultrasound with distilled water to remove impurities and milled. The carbonated powder was stored in a glass container. Each sample was placed to react with orthophosphoric acid to $100 \%$, at $25^{\circ} \mathrm{C}$ during 12 hours. The $\mathrm{CO}_{2}$ released during the reaction was extracted in a high vacuum line using cryogenic purification by following the method proposed by Craig (1957).

The "Kiel IV Carbonate Devise" equipment and "Delta V Plus - Isotope Ratio MS" analyzer (Thermo Scientific) were used for isotopic analysis. The obtained results are 
compared with a standard carbonate, the Pee Dee Belemnite (PDB). Data from carbon and oxygen isotopes are shown by the $\delta$ parameter defined by: $\delta(\%)=\left[\mathrm{R}_{\text {sample }}-\mathrm{R}_{\text {standard }}\right.$ $/$ Rstandard) $\times 1000$. In this parameter, $\mathrm{R}$ values correspond to $\mathrm{C}^{13} / \mathrm{C}^{12}$ and $\mathrm{O}^{18} / \mathrm{O}^{16}$. The accuracy of the analysis is 0.030 $\%$.

\subsection{Statistical analysis}

Only the most abundant and frequent species of benthic foraminifera along the core were considered in statistical analysis. Before to be submitted to statistical analysis, data were logarithmically transformed $[\log (x+1)]$. This work analyses Pearson correlations. Correlations are significant for $p>0.05$. Selected data also were submitted to Principal Components Analysis (PCA) to assess the relationship between selected variables. These analyzes were conducted in the software Statistica 12.0.

\section{RESULTS}

\subsection{The core age model of the core T1}

Table 1 presents the results of the radiocarbon dating. The radiocarbon results provide ages from 550 to $425 \mathrm{yr} \mathrm{cal}$ BP $(400 \pm 30 \mathrm{yr}$ cal BP), from 660 to $505 \mathrm{yr}$ cal BP $(540 \pm 30$ $\mathrm{yr}$ cal BP) and from 1400 to $1240 \mathrm{yr}$ cal BP $(1310 \pm 30 \mathrm{yr} \mathrm{cal}$ BP) for the depths $250 \mathrm{~cm}, 285 \mathrm{~cm}$ and $340 \mathrm{~cm}$, respectively. The estimated mean sedimentation rates were determined (ranging from $0.10 \mathrm{~cm} / \mathrm{yr}$ and $0.51 \mathrm{~cm} / \mathrm{yr}$ ) and presented in Table 1.

The model ages for the core T1 was obtained through linear interpolation of the results of radiocarbon data (Fig. 2 ). This age model suggests an age of $\approx 2400 \mathrm{yr}$ cal BP for the core base.

\subsection{Particle size of the core $T 1$}

Supplementary material 1 (SM1) presents data of sediment granulometry, namely percentage of coarse (1000$500 \mu \mathrm{m})$, medium $(500-250 \mu \mathrm{m})$, fine $(250-125 \mu \mathrm{m})$ and very fine sand $(125-63 \mu \mathrm{m})$, as well as very coarse $(63-31 \mu \mathrm{m})$, coarse $(31-16 \mu \mathrm{m})$, medium $(16-8 \mu \mathrm{m})$, fine $(8-4 \mu \mathrm{m})$, very fine silt $(4-2 \mu \mathrm{m})$ and clay $(<2 \mu \mathrm{m})$ fractions.

Figure 3 represents the stratigraphic column of the core T1. It shows that this core consists essentially of fine sand. It contains bioclasts (fragments of mollusk shells and entire valves) in its middle section. Oxidized plant fragments also were identified from $160 \mathrm{~cm}$ to the core top.

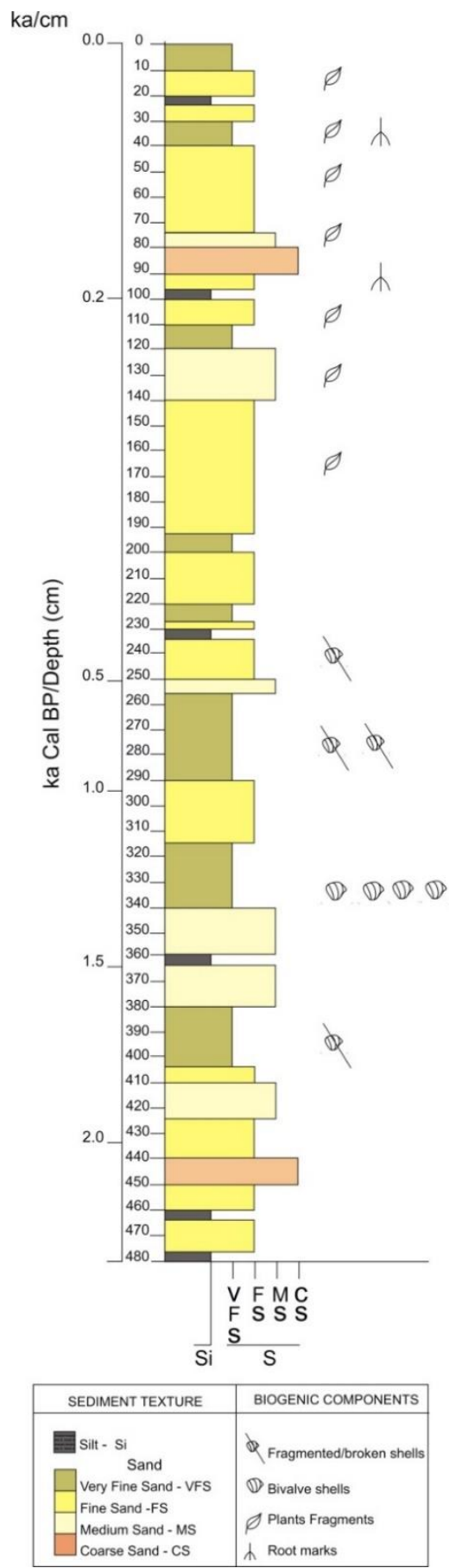

Fig. 3. Textural description of core T1. A depth (cm) and an age scales (ka cal BP) are presented. 
Tab. 1. Measured, conventional and calibrated Before Present (BP) and Ano Domine (AD) radiocarbon ages for the analyzed core levels. Evaluated mean sedimentation rate $(\mathrm{cm} / \mathrm{yr})$ are also presented.

\begin{tabular}{|c|c|c|c|c|c|c|}
\hline $\begin{array}{l}\text { Depth } \\
(\mathrm{cm})\end{array}$ & $\begin{array}{c}\text { Measured } \\
\text { Radiocabon } \\
\text { Age (BP) }\end{array}$ & $\begin{array}{l}\delta^{13} \mathrm{C} \\
(\% 0)\end{array}$ & $\begin{array}{c}\text { Conventional } \\
\text { Radiocarbon Age } \\
(\text { yr cal BP) }\end{array}$ & $\begin{array}{c}\text { Calibrated Age } \\
\text { Before Present } \\
\text { (yr cal BP) }\end{array}$ & $\begin{array}{l}\text { Calibrated Age } \\
\text { Ano Domine } \\
\text { (yr cal AD) }\end{array}$ & $\begin{array}{c}\text { Mean } \\
\text { Sedimentarion } \\
\text { rate }(\mathrm{cm} / \mathrm{yr})\end{array}$ \\
\hline 250 & $400 \pm 30$ & 0.1 & $810 \pm 30$ & $\begin{array}{c}550 \text { to } 425 \\
(488 \pm 63)\end{array}$ & $\begin{array}{c}1400 \text { to } 1525 \\
(1463 \pm 63)\end{array}$ & 0.51 \\
\hline 285 & $540 \pm 30$ & 0.8 & $940 \pm 30$ & $\begin{array}{c}660 \text { to } 505 \\
(583 \pm 78)\end{array}$ & $\begin{array}{c}1290 \text { to } 1445 \\
(1368 \pm 78)\end{array}$ & 0.10 \\
\hline 340 & $1310 \pm 30$ & 0.9 & $1710 \pm 30$ & $\begin{array}{c}1400 \text { to } 1240 \\
(1320 \pm 80)\end{array}$ & $\begin{array}{c}550 \text { to } 710 \\
(630 \pm 80)\end{array}$ & 0.13 \\
\hline
\end{tabular}

In the SM2 are presented the results of sedimentary mean grain size (SMGS, $\mu \mathrm{m}$ ), the particle size modes, as well as sorting $(\sigma)$, skewness $(\phi)$, kurtosis $(K)$ and sediment textural classification. Figure 4 includes depth plots of sediment mean grain size (SMGS, $\mu \mathrm{m})$, coarse + medium sand fractions $(\%)$ and fine fraction $(<63 \mu \mathrm{m}, \%)$. The values of sorting $(\sigma)$, skewness $(\phi)$ and kurtosis $(K)$ are also included in this figure. These plots show that the values of SMGS (ranging from $31 \mu \mathrm{m}$ to $598 \mu \mathrm{m}$, average $185 \mu \mathrm{m}$ ) increase cyclically, such as between $450-400 \mathrm{~cm}, 370-340 \mathrm{~cm}, 255-240$ $\mathrm{cm}, 175-115 \mathrm{~cm}$ and $90-60 \mathrm{~cm}$. These sections with coarser grain size are characterized mainly by the increase of total coarse + medium sand fractions $(1000-250 \mu \mathrm{m})$.

The sediments of the core T1 are composed mainly by sand fraction (>63 $\mu \mathrm{m} ; 94-24 \%$, average $69 \%$ ). The fine fraction $(<63 \mu \mathrm{m})$ content varies between $69-6 \%$ (average $30 \%)$. The most abundant fine fraction is coarse silt (63-31 $\mu \mathrm{m}$ ), ranging from $29 \%$ to $1 \%$ (average 15\%; SM1). Among the fine fractions, clay fraction $(<2 \mu \mathrm{m})$ is the less abundant $(<7 \%$; SM1). The sediments grain sizes of this core are in general composed by two modes of particle size. The average values of mode 1 is $\approx 380 \mu \mathrm{m}$ and of mode 2 is $\approx 243 \mu \mathrm{m}$. In the coarser sections, the sediments only display one granulometric mode, which can also be observed in the finest core layers.

Sorting $(\sigma)$ values ranged from 5.94 to 2.04 , at $480 \mathrm{~cm}$ and $440 \mathrm{~cm}$, respectively (average 3.46, SM2). Thus, the core T1 is composed mostly of poorly sorted fine and very fine sand (SM1). Sediment skewness ( $\phi$, or symmetry) varies between 0.16 and -0.67 (average -0.18). The sediments are mostly symetrical to very fine skewed. Skewness values become much more negative in layers with coarser sediments, between $440-425 \mathrm{~cm}(-0.48$ to -0.37$), 370-340 \mathrm{~cm}$
(-0.61 to -0.54$)$, and $85 \mathrm{~cm}(-0.64)$. The most positive values of skewness were identified in the layers of $315 \mathrm{~cm}(0.12)$, $275 \mathrm{~cm}(0.13), 195 \mathrm{~cm}(0.15)$ and $65 \mathrm{~cm}(0.13)$, all containing predominantly very fine sand. The kurtosis values oscillate in turn of a medium value (1.01) along the core, with predominance of mesokurtic sediments.

\subsection{Geochemistry}

The SM1 presents the results of total organic carbon (TOC, $\%$ ), total sulfur (S, \%), calcium carbonate $\left(\mathrm{CaCO}_{3}\right.$, $\%$ ). In Figure 5, the depth plot of sediment mean grain size (SMGS, $\mu \mathrm{m})$ is compared with TOC (\%), $\mathrm{CaCO}_{3}(\%)$ and $\mathrm{S}$ (\%). TOC content ranges from $0.62 \%$ to $7.03 \%$. TOC values below the average $(1.85 \%)$ were recorded in the section 480 $130 \mathrm{~cm}$. In the upper $250 \mathrm{~cm}$, there is a tendency to the TOC content increasing $\left(\mathrm{R}^{2}=0.66\right.$; Fig. 5).

Calcium carbonate content varied between $10 \%$ and $23 \%$ (average 16\%). An upward increasing trend of this variable values is observed $\left(\mathrm{R}^{2}=0.63\right.$, Fig. 5). The $\mathrm{S}$ content ranged from $0.12 \%$ to $1.13 \%$ (average $0.63 \%$ ). In general, lower $\mathrm{S}$ contents were registered in the sections $350-120 \mathrm{~cm}$ and $40-$ $0 \mathrm{~cm}$. Between 350 and $120 \mathrm{~cm}$, there are relatively low TOC concentrations. The highest values of TOC of core T1 were recorded in the section $40-0 \mathrm{~cm}$.

Stable isotope data were obtained in the section 340-185 $\mathrm{cm}$, due to the presence of enough calcareous foraminifera. In that section, A.tepida $\delta^{18} \mathrm{O}$ values ranged from $-4.769 \%$ to $-1.201 \%$ and of A.tepida $^{13} \mathrm{C}$ between $-4.598 \%$ and $-1.851 \%$ (Table 2). Figure 6 presents the depth plots of A.tepida $^{18} \mathrm{O}$ and A.tepida $\delta^{13} \mathrm{C}$. These depth plots evidence that these data varied 
cyclially. Simultaneous increases of ${ }_{A . t p p i d a} \delta^{18} \mathrm{O}$ and ${ }_{\text {A.tpida }} \delta^{13} \mathrm{C}$ values are observed.

Tab. 2. Values of ${ }_{\text {A.tepida }} \delta^{18} \mathrm{O}(\% 0)$ and ${ }_{\text {A.tepida }} \delta^{13} \mathrm{C}(\% 0)$ in the section $340-185 \mathrm{~cm}$ of core $\mathrm{T} 1$.

\begin{tabular}{ccc}
\hline Depth (cm) & A.tepida $\boldsymbol{\delta}^{\mathbf{1 8}} \mathbf{O} \mathbf{( \% \mathbf { 0 } )}$ & A.tepida $\boldsymbol{\delta}^{\mathbf{1 3}} \mathbf{C} \mathbf{( \% \mathbf { 0 } )}$ \\
\hline 185 & -1.201 & -1.851 \\
195 & -1.397 & -2.237 \\
205 & -1.434 & -2.487 \\
220 & -1.470 & -2.675 \\
230 & -1.528 & -2.490 \\
240 & -1.532 & -1.583 \\
250 & -1.625 & -2.395 \\
260 & -1.808 & -2.753 \\
275 & -1.869 & -2.610 \\
285 & -2.184 & -3.096 \\
295 & -2.438 & -2.492 \\
305 & -2.879 & -3.574 \\
315 & -4.409 & -4.437 \\
340 & -4.769 & -4.598 \\
\hline
\end{tabular}

\subsection{Benthic foraminifera}

The amount of 31 species of benthic foraminifera was identified, 15 calcareous and 16 agglutinated (SM3). The results of foraminifera density $\left(\mathrm{n}^{\circ} / 10 \mathrm{ml}\right)$ and species richness (SR, number of species per sample) can be observed in SM1. Foraminifera density along the core ranged from 0 to 325 specimens $/ 10 \mathrm{ml}$. Foraminifera are rare or absent between $480-350 \mathrm{~cm}$, at $130 \mathrm{~cm}$, between $95-75 \mathrm{~cm}$ and between $55-30 \mathrm{~cm}$. The highest foraminifera density was observed between $340-165 \mathrm{~cm}$, at $110 \mathrm{~cm}$, at $65 \mathrm{~cm}$ and in the first $20 \mathrm{~cm}$ of the core.

In the section $340-165 \mathrm{~cm}$, foraminifera assemblages are composed mostly of calcareous species. Instead, at $110 \mathrm{~cm}$, $65 \mathrm{~cm}$ and in the first $20 \mathrm{~cm}$ of the core, these assemblages include mostly agglutinated foraminifera. Between 195-175 $\mathrm{cm}$, the assemblages contain both calcareous and agglutinated foraminifera.

Specific richness (SR) varied between 0-11 species per sample, reaching the highest values in the sections with higher foraminifera density. Foraminifera density and SR reach the highest values in the section $315-260 \mathrm{~cm}$, where the highest values of $A_{\text {.tepida }} \delta^{18} \mathrm{O}$ and $A_{\text {.tepida }} \delta^{13} \mathrm{C}$ are recorded
(Fig. 6). A reduction of ${ }_{\text {A.tepida }} \delta^{13} \mathrm{C}$ values seems to occur in the section $230-185 \mathrm{~cm}$ followed by a general reduction of foraminifera density and SR (Fig. 6). This trend is less clear for A.tepida $^{18} \mathrm{O}$.

The list of species identified along the core T1 is presented in SM3 and the species density $\left(\mathrm{n}^{\circ} / 10 \mathrm{ml}\right)$ in SM4. The most abundant and common species along the core are Ammonia parkinsoniana, Ammonia tepida, Ammonia sp., Arenoparrella mexicana, Cribroelphidium excavatum, Cribroelphidium poeyanum, Elphidium gunteri, Elphidium sp., Entzia macrescens, Haynesina germanica and Trochammina inflata.

Figure 7 presents the depth plots of absolute abundance $\left(\mathrm{n}^{\circ} / 10 \mathrm{ml}\right)$ of the main taxa and species groups of benthic foraminifera of the core T1. Ammonia parkinsoniana, A. tepida, Criboelphidium/Elphidium spp. and $H$. germanica are the most abundant species in the section 340-165 cm. In addition, the species Bolivina striatula and Buliminella elegantissima have also significant occurrences between $350-175 \mathrm{~cm}$. Instead, in the upper $150 \mathrm{~cm}$, where foraminifera assemblages are composed only by agglutinated foraminifera, the most abundant species is $A$. mexicana. Other species were also observed, such as, E. macrescens, Haplophragmoides manilaensis, Haplophragmoides wilberti, Miliammina fusca and T. inflata.

\subsection{Statistical results}

In SM5 are presented the Pearson's correlations obtained for all analyzed layers of the core T1 considering the following variables: SMGS $(\mu \mathrm{m})$, very fine sand fraction (63$125 \mu \mathrm{m}, \%)$, TOC (\%), S (\%), foraminifera density $\left(\mathrm{n}^{\circ} / 10\right.$ $\mathrm{ml})$. The abundance $\left(\mathrm{n}^{\circ} / 10 \mathrm{ml}\right)$ of the following species was also considered: $A$. parkinsoniana, A. tepida, A. mexicana, $B$. striatula, B. elegantissima, C. excavatum, $C$. poeyanum, Cribroelphidium vadescens, Elphidium discoidale, E. gunteri, Elphidium sp., E. macrescens, H. germanica and T. inflata.

The SM5 shows that: i) very fine sand fraction (63-125 $\mu \mathrm{m})$ has significant positive correlations with foraminifera density and SR; ii) TOC has significant positive correlations with $\mathrm{CaCO}_{3}, A$. mexicana, T. inflata and E. macrescens and negative one with most of the calcareous species such as $A$. parkinsoniana, A. tepida, B. striatula, B. elegantissima, $C$. excavatum, C. poeyanum, E. discoidale, E. gunteri and H. germanica; iii) the main calcareous species have significant positive correlations with each other; iv) $A$. tepida has significant positive correlation with B. elegantissima; v) A. parkinsoniana displays significant positive correlation with $B$. striatula; and vi) $\mathrm{S}$ has significant negative correlations with $\mathrm{CaCO}_{3}, \mathrm{SR}$, foraminifera density and several calcareous species, such as A. parkinsoniana, A. tepida, A. mexicana, C. excavatum, $C$. poeyanum, T. inflata and E. macrescens. 


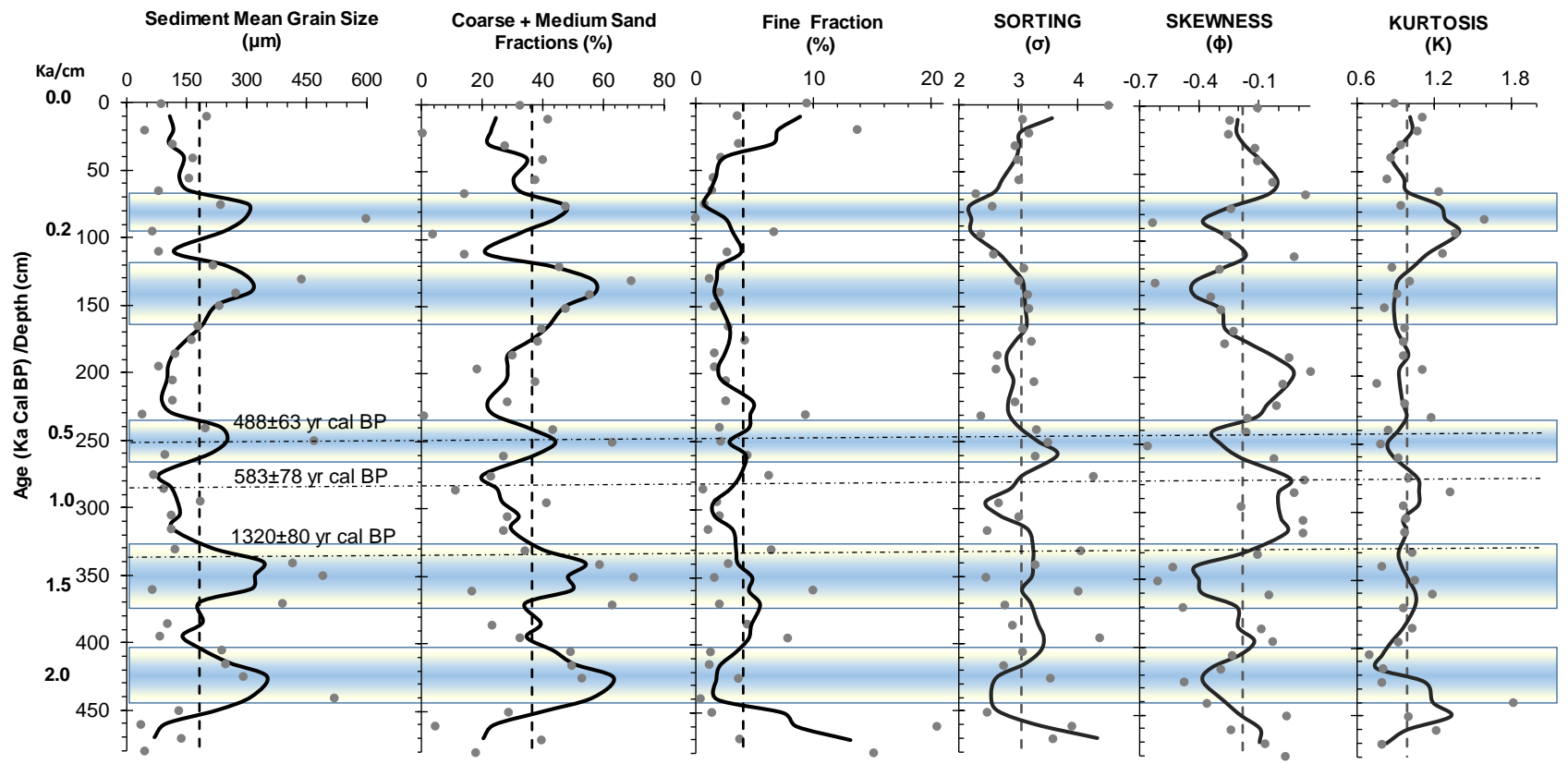

Fig. 4. Depth plots of sediment mean grain size (SMGS; $\mu \mathrm{m})$, coarse + medium sand fractions $(\%)$ and fine fraction $(\%)$. The values of sorting $(\sigma)$, skewness $(\phi)$ and kurtosis $(K)$ are also included in this figure. The values of each variable are represented by points, the mean of the values in black dotted line, and the moving mean average with the black solid line. An age scale based on estimated yr cal BP are represented as well as the radiocarbon results of the dated levels.

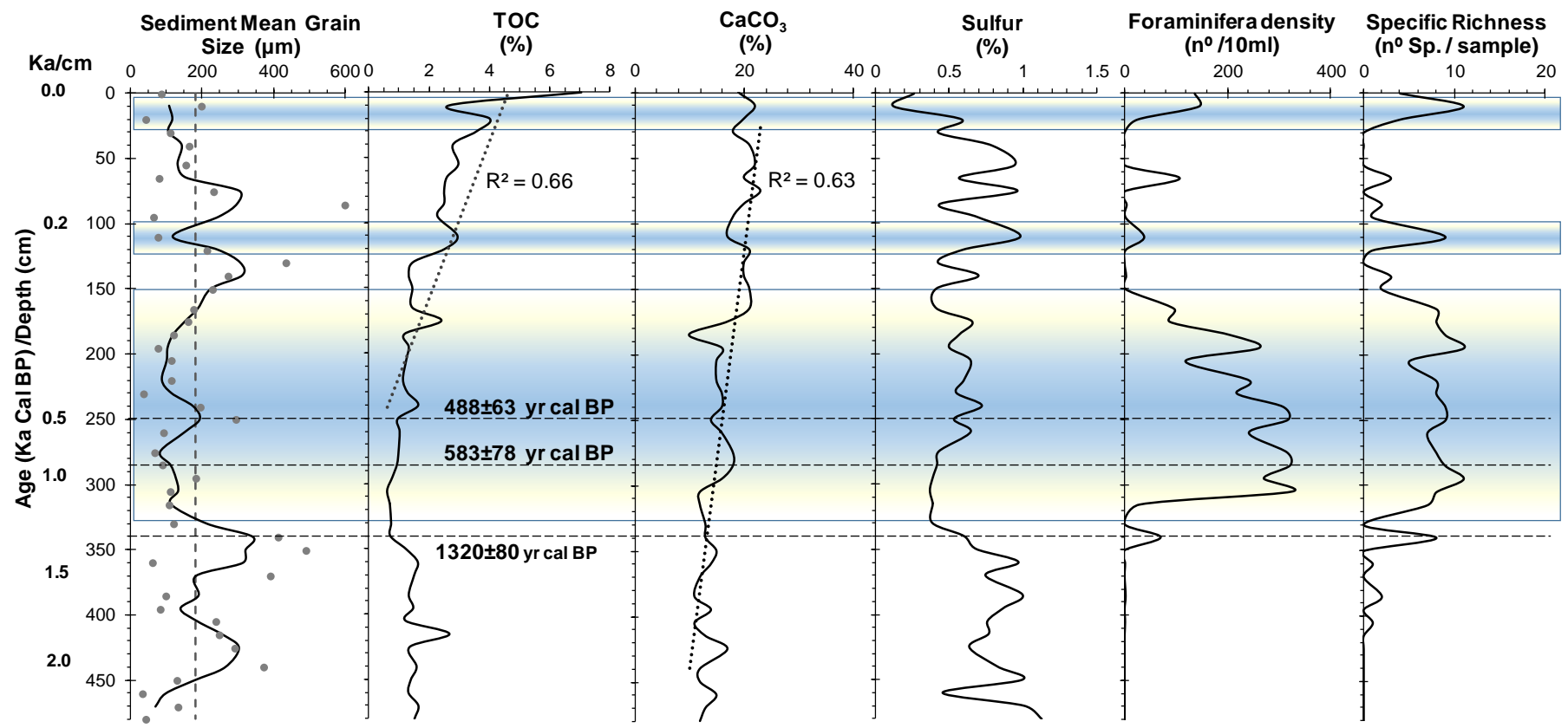

Fig. 5. Depth plots of sediment mean grain size (SMGS; $\mu \mathrm{m})$, TOC (\%), $\mathrm{CaCO}_{3}(\%)$ and S (\%) and biotic parameters - foraminifera density $\left(\mathrm{n}^{\circ} / 10 \mathrm{ml}\right)$ and species richness. In the depth plot data are represented by points, the mean of the values in grey dotted line and the moving mean average with the black solid line. An age scale based on estimated yr cal BP are represented as well as the radiocarbon results of the dated levels. 
The correlations between these variables are expressed in the results of the two first factors, of PCA presented in Figure 8A. The biplot of Factor 1 against Factor 2 (which explains $58 \%$ of data variability) allow us to distinguish four main groups of variables. These groups are composed of the following variables: I - TOC and S; II - SR, foraminifera density, very fine sand fraction $(63-125 \mu \mathrm{m})$, A. parkinsoniana, A. tepida, B. elegantissima, B. striatula, C. excavatum, C. poeyanum, C. vadescens, E. discidale, E. gunteri and H. germanica; and IIITOC, $\mathrm{CaCO}_{3}$, A. mexicana, E. macrescens and T. inflata; IV - S.

Total organic carbon is the only variable with significant positive correlation $(p>0.50)$ with the Factor 1, which explains 0.40 of data variability (Table 3 ). This factor has significant negative correlations with several variables, such as: SR, foraminifera density, $A$. parkinsoniana, $A$. tepida, B. striatula, C. excavatum, C. poeyanum, C. vadescens, E. discidale, E. gunteri, Elphidium sp. and H. germanica. Factor 2 (which explains 0.18 of data variability) has significant positive correlation $(p>0.50)$ with TOC, E. macrescens, T. inflata and A. mexicana.
Figure 9 includes the depth plots of the Factor Score 1 and 2 along the core T1 of the PCA of Figure 8A, in comparison with foraminifera density, abundance of agglutinated species and the values of $\mathrm{C} / \mathrm{S}$ ratio. The values of Factor Score 1 decrease significantly in turn of $\approx 340 \mathrm{~cm}$ and in the section $330-165 \mathrm{~cm}$ in coincidence with foraminifera density increase. Factor Score 2 increases mostly at $195 \mathrm{~cm}, 110 \mathrm{~cm}, 65 \mathrm{~cm}$ and in the first $20 \mathrm{~cm}$. The rise of Factor Score 2 values corresponds to the rises of agglutinated foraminifera abundance. The values of $\mathrm{C} / \mathrm{S}$ ratio increase slightly between $175-30 \mathrm{~cm}$ and have a very sharp rise from $20 \mathrm{~cm}$ to the core top.

In the section $185-340 \mathrm{~cm}$, stable isotopic data (obtained in $A$. tepida tests) were confronted through the Pearson's correlations (SM6) with selected variables (SR, foraminifera density, species abundance and abiotic parameters). The values of ${ }_{A . t e p i d d}{ }^{18} \mathrm{O}$ and ${ }_{A . t e p i d a} \delta^{13} \mathrm{C}$ have significant positive correlations with each other and with SR, foraminifera density, A. mexicana, B. elegantissima and B. striatula. The values of $A_{\text {teppida }} \delta^{18} \mathrm{O}$ also are positively correlated with TOC content.

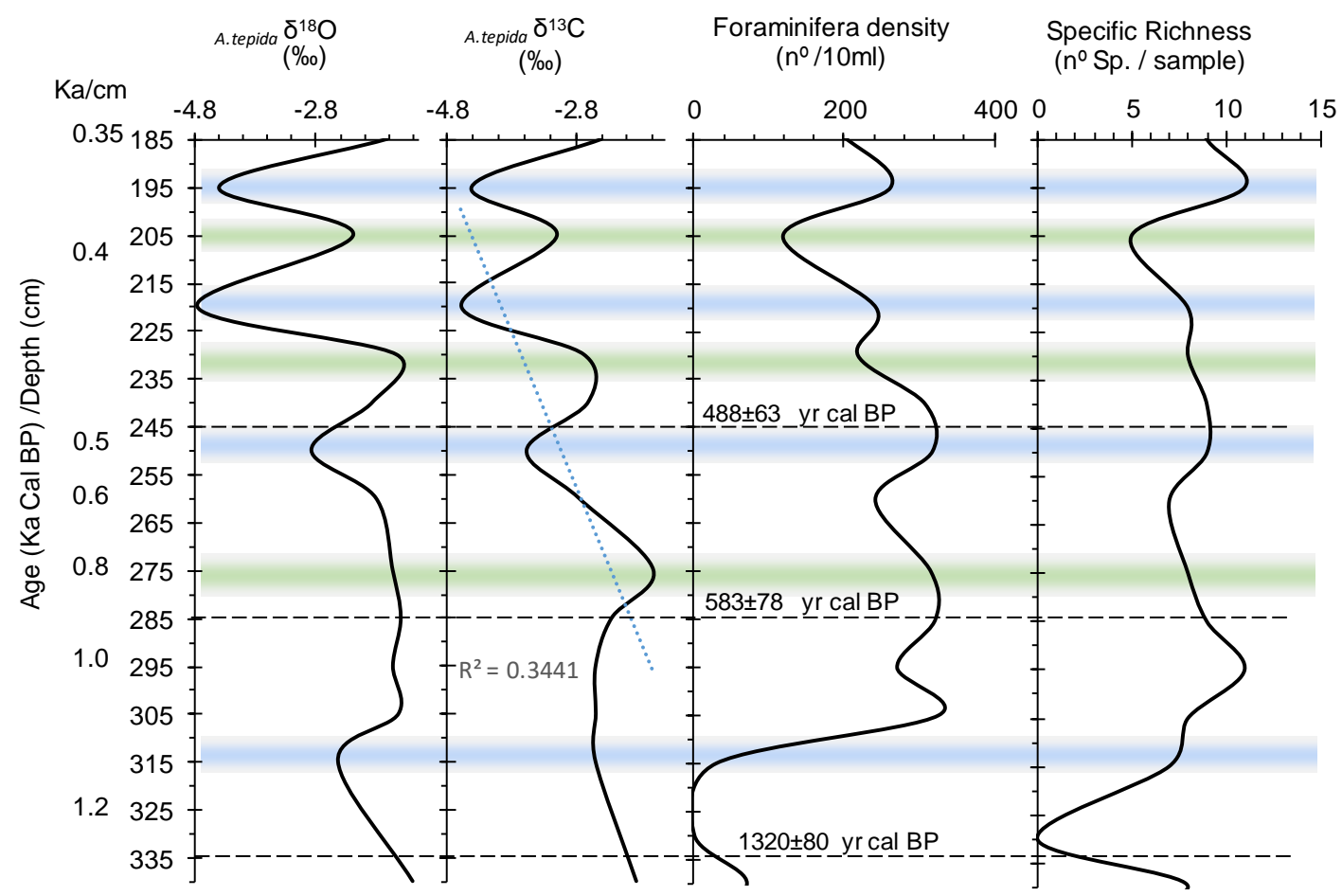

Fig. 6. Isotopic values of ${ }_{\text {A.tepida }} \delta^{13} \mathrm{C}$ and ${ }_{\text {A.tepida }} \delta^{18} \mathrm{O}$, foraminifera density $\left(\mathrm{n}^{\circ} / 10 \mathrm{ml}\right.$ ) and $\mathrm{SR}$ (number of species per sample) between 340 $185 \mathrm{~cm}$ on the core T1. An age scale based on estimated yrs cal BP are represented as well as the evaluated radiocarbon dates. 
Tab. 3. The variables with significant correlations $(p>0.50)$ with Factors 1 and 2, which explains $58 \%$ of data variability, of PCA analysis (Fig. 8). Significant correlations are marked in bold.

\begin{tabular}{|c|c|c|}
\hline Variables / Factors & $\begin{array}{c}\text { Factor } \\
1\end{array}$ & $\begin{array}{c}\text { Factor } \\
2\end{array}$ \\
\hline Sediment mean grain size $(\mu \mathrm{m})$ & 0.18 & -0.25 \\
\hline Very fine sand fraction $(\%)$ & -0.35 & 0.21 \\
\hline Total organic carbon (\%) & 0.50 & 0.58 \\
\hline Total Sulfur $(\%)$ & 0.40 & -0.43 \\
\hline Calcium carbonate $(\%)$ & 0.13 & 0.41 \\
\hline $\begin{array}{l}\text { Species Richness ( } \mathrm{n}^{\circ} \text { species } \\
\text { /sample) }\end{array}$ & -0.84 & 0.37 \\
\hline Foraminifera Density ( $\left.\mathrm{n}^{\circ} / 10 \mathrm{ml}\right)$ & -0.89 & 0.35 \\
\hline Ammonia parkinsoniana $\left(\mathrm{n}^{\circ} / 10 \mathrm{ml}\right)$ & -0.91 & -0.06 \\
\hline Ammonia tepida $\left(\mathrm{n}^{\circ} / 10 \mathrm{ml}\right)$ & -0.96 & -0.10 \\
\hline Arenoparrella mexicana $\left(\mathrm{n}^{\circ} / 10 \mathrm{ml}\right)$ & 0.06 & 0.90 \\
\hline Bolivina striatula $\left(\mathrm{n}^{\circ} / 10 \mathrm{ml}\right)$ & -0.70 & 0.08 \\
\hline Buliminella elegantissima $\left(\mathrm{n}^{\circ} / 10 \mathrm{ml}\right)$ & -0.43 & 0.30 \\
\hline Cribroelphidium poeyanum (nº $/ 10 \mathrm{ml})$ & -0.90 & -0.23 \\
\hline Cribroelphidium vadescens $\left(\mathrm{n}^{\circ} / 10 \mathrm{ml}\right)$ & -0.57 & 0.13 \\
\hline Elphidium discoidale $\left(\mathrm{n}^{\circ} / 10 \mathrm{ml}\right)$ & -0.51 & -0.22 \\
\hline Cribroelphidium excavatum $\left(\mathrm{n}^{\circ} / 10 \mathrm{ml}\right)$ & -0.92 & -0.22 \\
\hline Elphidium gunteri ( $\left.\mathrm{n}^{\mathrm{o}} / 10 \mathrm{ml}\right)$ & -0.76 & -0.23 \\
\hline Elphidium sp. (nº $/ 10 \mathrm{ml})$ & -0.62 & -0.10 \\
\hline Haynesina germanica $\left(\mathrm{n}^{\circ} / 10 \mathrm{ml}\right)$ & -0.83 & 0.06 \\
\hline Trochammina inflata $\left(\mathrm{n}^{\circ} / 10 \mathrm{ml}\right)$ & -0.02 & 0.88 \\
\hline Entria macrescens (nº $/ 10 \mathrm{ml})$ & -0.10 & 0.86 \\
\hline Explained variability & 0.40 & 0.18 \\
\hline
\end{tabular}

These correlations are expressed in the groups established by the PCA of Figure 8B. In the biplot of the two first factors of this PCA (which explain $51 \%$ of data variability), we can highlight the group II (which is related to finer grained sediments since it is in opposition to group I, composed by medium to coarse sand fractions) and is composed of the following variables: A.tepida $\mathrm{O}^{18} \mathrm{O}$ and A.tepida $\mathrm{S}^{13} \mathrm{C}$, TOC, SR, foraminifera density, $\mathrm{CaCO}_{3}, A$. parkinsoniana, A. tepida, H. germanica, C. poeyanum and $C$. vadescens.

Group III of this PCA also group B. striatula, B. elegantissima, A. mexicana, E. macrescens and T. inflata with TOC. These results evidences that the most positive stable isotopic values are related to the rise of TOC, foraminifera density, due to the expansion of several calcareous species, and diversity. They also show that in an environment characterized by relatively low concentrations of TOC, the increase of this variable determine a proliferation of $B$. striatula, B. elegantissima and of the reported agglutinated species.

\section{DISCUSSION}

\subsection{Sedimentological characteristics of core T1}

The sediments of the core T1 are composed essentially of lithogenic materials including mostly quartz. It also displays in the middle section of the core (between 340-150 $\mathrm{cm}$ ) abundant carbonated biogenic particles (mollusk shells and foraminifera tests). Terrestrial plant remains are observed in the first $150 \mathrm{~cm}$.

This core is composed mostly of poorly sorted fine and very fine sand with a coarser constituent (composed of medium to coarse sand) that increases cyclically (such as at $450-400 \mathrm{~cm}, 370-340 \mathrm{~cm}, 255-240 \mathrm{~cm}, 175-115 \mathrm{~cm}$ and $90-$ $60 \mathrm{~cm}$ ). These characteristics reveal that the hydrodynamism related to transport and deposition of the sediments changed from moderate to relatively high during the last $2400 \mathrm{yrs} \mathrm{cal}$ $\mathrm{BP}$, in the study area.

The occurrence of stronger hydrodynamic conditions occurred at a centennial scale, around for instance: $\approx 2000$ yrs cal BP, $\approx 1500 \mathrm{yrs} \mathrm{cal} \mathrm{BP}, \approx 500 \mathrm{yrs} \mathrm{cal} \mathrm{BP}, \approx 250 \mathrm{yrs} \mathrm{cal}$ $\mathrm{BP}$ and $\approx 100 \mathrm{yrs} \mathrm{cal} \mathrm{BP}$.

On the other hand, in the section $340-165 \mathrm{~cm}$, the sediments tend to be in general finer and to have lower values of sorting and skewness and intermediate values of kurtosis. These results suggest that the sediments deposited between $\approx 1300 \mathrm{yrs} \mathrm{cal} \mathrm{BP}$ and $\approx 300 \mathrm{yrs} \mathrm{cal} \mathrm{BP}$ tended to be better sorted, coarser skewed and more platykurtic, except around $500 \mathrm{yrs}$ cal BP. These textural characteristics indicate a longer prevalence of relatively weak and less variable conditions which were interrupted by stronger hydrodynamic events at about $500 \mathrm{yrs}$ cal BP.

The percentage of TOC and $\mathrm{S}$ in the sediments deposited in the period $\approx 1300-300$ yrs cal BP (between $340-165 \mathrm{~cm}$, the middle section of the core) is relatively low, but display well preserved shells and bioclasts of mollusks and relatively high density of calcareous benthic foraminifera.

The sediments tend to be also finer in the upper section of the core, corresponding to the last $\approx 100 \mathrm{yrs}$ cal BP (the upper $50 \mathrm{~cm}$ ). In this period, the values of sorting and kurtosis tend to rise, and skewness to decrease. These 
characteristics reveal that the sediments became each more poorly sorted, less coarse skewed and more lepticurtic, which should be related to each more low hydrodynamics but intercalated with phases with more energetic currents.

These reported textural features agree with the current Guaratiba Mangrove setting, which is a low energy intertidal zone (Pereira et al., 2007)

The $\mathrm{S}$ content tends to rise in the sections where TOC percentage is relatively high. However, $\mathrm{S}$ has the lowest concentrations in the upper core section, where there are the highest TOC concentrations.
These results indicate that the $\mathrm{S}$ values should be related essentially to diagenetic reactions arising from organic matter degradation and biogenic formation of pyrite ( $\mathrm{FeS})$, in anoxic environments (Saunders et al. 1997; Kohn et al. 1998).

The reduction of $S$ concentrations in the upper $40 \mathrm{~cm}$ of this core should be related to less favorable conditions for pyrite formation and preservation, regardless of the highest TOC content (Martins et al., 2015a).

The relatively large spaces between the sandy grains allows the oxygen penetration and the anoxia is established in deep layers of the sedimentary column.

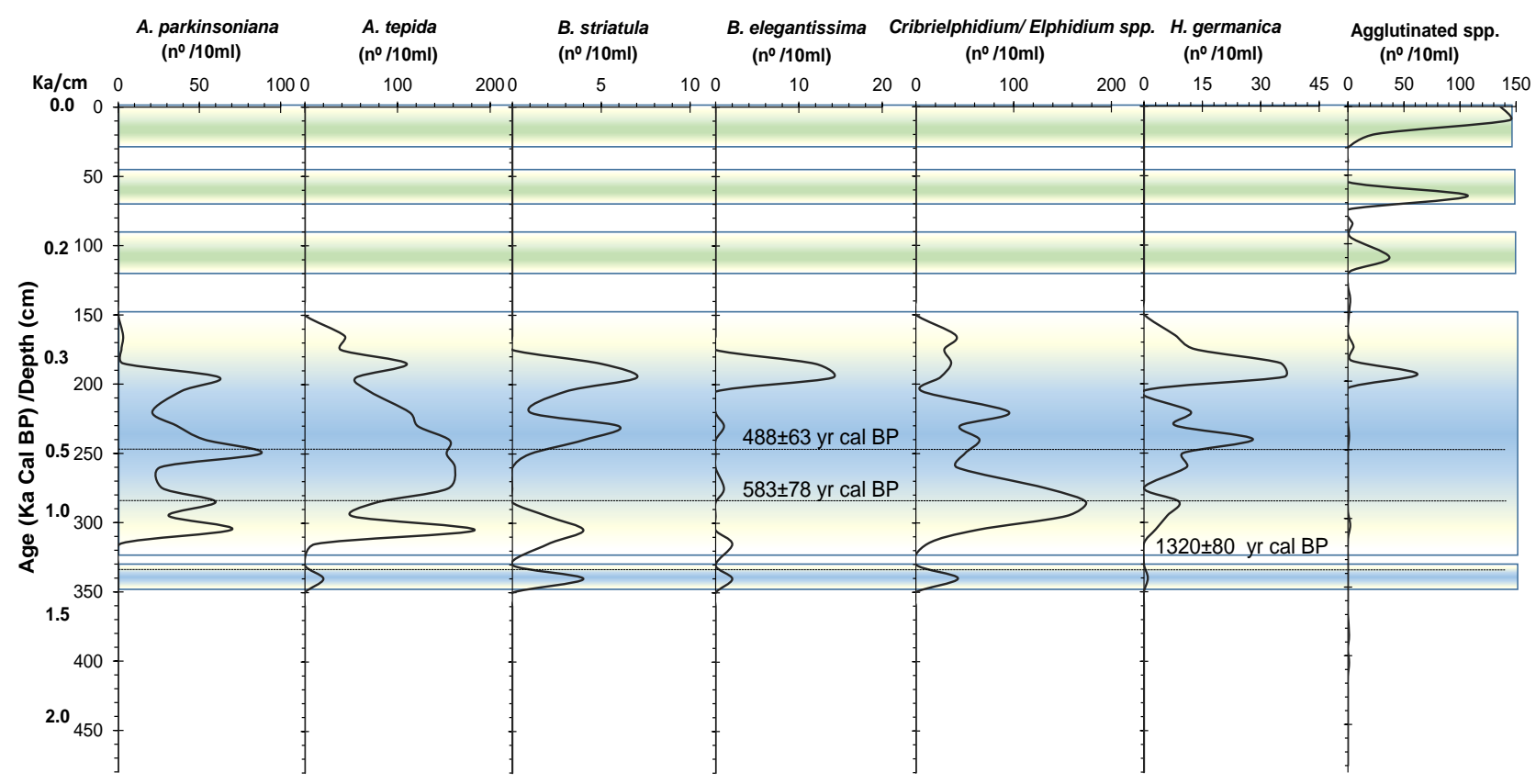

Fig. 7. Presents the depth plots of absolute abundance $\left(\mathrm{n}^{\circ} / 10 \mathrm{ml}\right)$ of the main taxa and species groups of benthic foraminifera from core T1. An age scale based on estimated yrs cal BP is represented as well as the radiocarbon results of the dated levels.

\subsection{Foraminifera assemblages composition}

The benthic foraminifera assemblages along the core T1 display relatively low species richness, including mostly $A$. parkinsoniana, A. tepida, A. mexicana, C. excavatum, C. poeyanum, E. gunteri, Elphidium sp., H. germanica, T. inflata and E. macrescens. This kind of species are common in the Guaratiba Mangrove as well as in Sepetiba Bay, as observed by Zaninetti et al. (1976, 1977), Brönnimann et al. (1981a, b), Laut et al. (2006, 2009, 2012, 2014) and Laut and Rodrigues (2011). They are also common in other worldwide transitional systems (Murray 1991, 2006; Coccioni et al., 2009; Frontalini et al., 2009, 2010, 2011; Camacho et al.,
2015; Clemente et al., 2015; Laut et al. 2016; Martins et al., 2010, 2011, 2013, 2014, 2015b, c, d, 2016).

The dimension and structure of the benthic foraminifera assemblages present significant changes along the core T1. These variations are partially related to the sediments grain size and composition, as indicated by the results of the PCA shown in Figure 8A and Pearson's correlations (SM5).

The arrangement of Group II of the PCA (Figure 8A) shows that $\mathrm{SR}$ and foraminifera density and the abundance of A. parkinsoniana, A. tepida, B. striatula, B. elegantissima, $C$. excavatum, C. poeyanum, C. vadescens, E. discidale, E. gunteri and H. germanica are mostly related to the increase in the very fine sand fraction $(63-125 \mu \mathrm{m})$. 

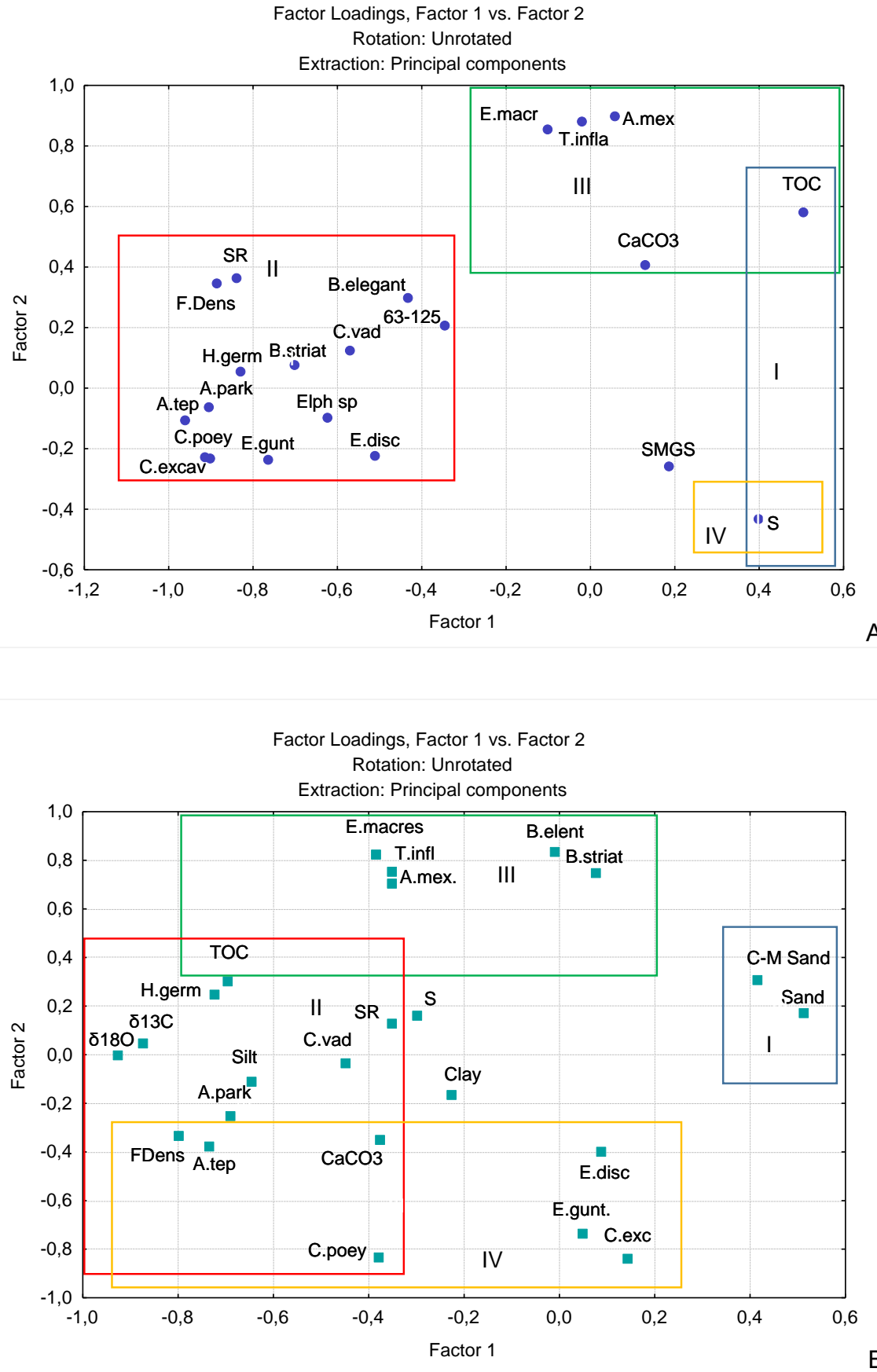

Fig. 8. Principal Components Analysis (PCA) results based on the most significant variables (species abundance and abiotic parameters). A - in all the studied core T1 layers; B - based on the core T1 layers with isotopic data, this is in the section 185-340 cm. Figure legend: SMGS - sediment mean grain size $(\mu \mathrm{m}) ; 63-125$ - very fine sand fraction (\%); TOC - total organic carbon (\%); S- total sulfur $(\%)$; CaCO 3 - calcium carbonate (\%); SR - species richness ( $\mathrm{n}^{\circ}$ species /sample); F.Dens - foraminifera density ( $\left.\mathrm{n}^{\circ} / 10 \mathrm{ml}\right) ;$ A.park - Ammonia parkinsoniana ( $\left.\mathrm{n}^{\circ} / 10 \mathrm{ml}\right)$; A.tep - Ammonia tepida $\left(\mathrm{n}^{\circ} / 10 \mathrm{ml}\right) ;$ A.mex - Arenoparrella mexicana $\left(\mathrm{n}^{\circ} / 10 \mathrm{ml}\right) ; \mathrm{B} . \mathrm{striat}^{-}$Bolivina striatula $\left(\mathrm{n}^{\circ} / 10\right.$

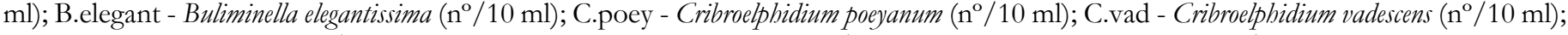

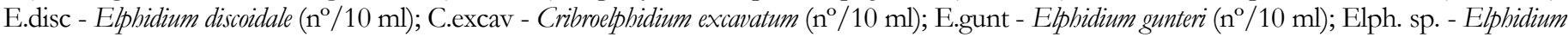

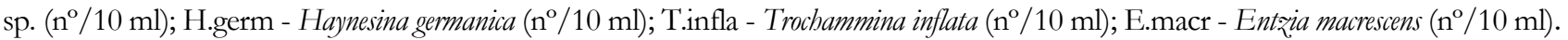




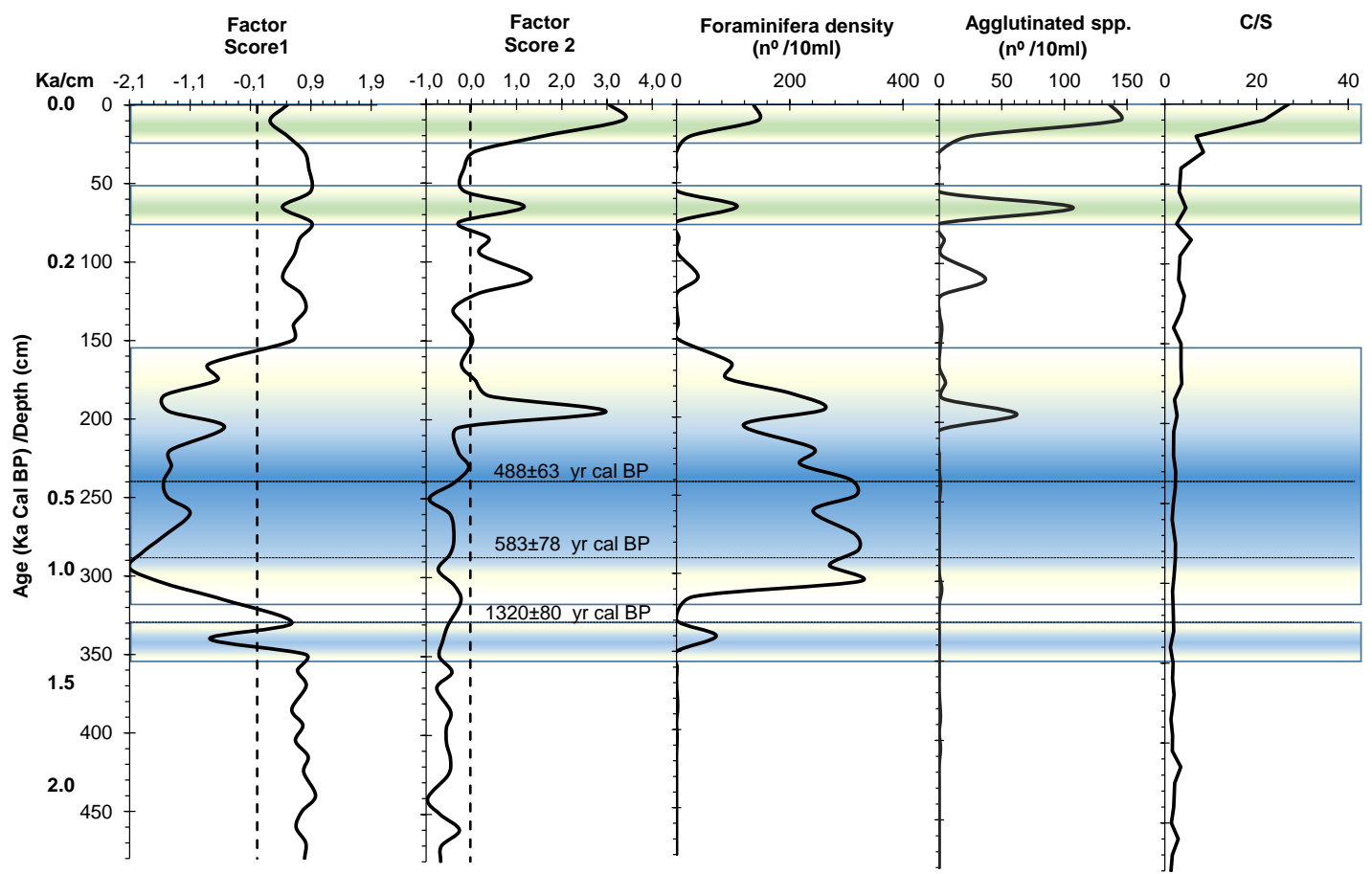

Fig. 9. Depth plot of the factor scores 1 and 2 along the core T1 (in solid black line and the mean of the values for each factor in black dotted line). These graphs are compared with the depth plots of foraminifera density ( $\mathrm{n}^{\circ} / 10 \mathrm{ml}$ ), abundance of agglutinated species $\left(\mathrm{n}^{\circ} / 10 \mathrm{ml}\right)$ and the values of the $\mathrm{C} / \mathrm{S}$ ratio. An age scale based on estimated yr cal BP are represented as well as the evaluated radiocarbon dates. The blue bands represent an immersion period of the study area and the green bands represent the development and establishment of the current mangrove.

Inversely, the species E. macrescens, T. inflata and $A$. mexicana are mostly linked with TOC and $\mathrm{CaCO}_{3}$ enrichment. These variables reach the highest values in the core top, where calcareous species are absent giving place to agglutinated fauna as referred. These results suggest that benthic foraminifera assemblages dimension and structure were influenced by the hydrodynamics and the evolution of environmental conditions.

The Factor 1 of the PCA (Figure 8A) has significant positive correlation of with TOC and the negative with SR, foraminifera density, A. parkinsoniana, A. tepida, B. striatula, $C$. excavatum, C. poeyanum, C. vadescens, E. discidale, E. gunteri, Elphidium sp. and $H$. germanica indicate a strong negative impact of the excessive enrichment of organic matter on the microfauna. The extreme enrichment of organic matter causes the reduction of benthic foraminifera dimension and diversity and the loose of the calcareous species in the upper core layers deposited in last $\approx 300$ yrs cal BP (upper $150 \mathrm{~cm}$ ).

Else processes of organic matter degradation produce organic acids which can contribute to the $\mathrm{pH}$ declining in the sediments and to the dilution of calcareous tests (Martins et al., 2015 b, c) or to cause foraminifera inability to calcify the walls of their tests (Nooijer et al., 2009; Uthicke et al., 2013).

We should expect that the reduction of $\mathrm{pH}$ has been the main cause of the complete decline of the calcareous species in the last $\approx 300 \mathrm{yrs}$ cal BP (upper $150 \mathrm{~cm}$ ). However, this seems not to be completely true, since a gradual upward increase in carbonate content is observed. Else, the highest percentages of carbonates are found in the upper $160 \mathrm{~cm}$ of the core T1 in coincidence with the highest TOC content.

These results indicate that carbonates of these sediments are not only related to materials from the source rocks eroded by the rivers and supplied to the study area. Carbonates can also be deposited in evaporitic series under dry environments (e.g. Warren, 1989, 1999; Rouchy et al., 2001). This possibility agrees with the present day characteristics of Guaratiba Mangrove, a hypersaline transitional ecosystem (Pereira et al., 2007), which seems to be favorable to the precipitation of carbonates.

In the middle core section $(340-150 \mathrm{~cm})$, the sediments are fine grained, but the TOC values are relatively low. This section is characterized by a diversified and abundant fauna 
of foraminifers dominated by calcareous species. In such conditions, foraminifera fauna answers positively to the slight increase in organic matter. This is indicated by both SR and foraminifera density and by the abundance of $A$. parkinsoniana, A. tepida, H. germanica, C. poeyanum and $C$. vadescens (Fig. 8B; Group II). This is also suggested by the increase of species such as B. striatula, B. elegantissima, $A$. mexicana, E. macrescens and T. inflata (Figure 8B; Group III). These species are known to be linked to high organic matter content in this region (Laut et al. 2006, 2009, 2011, 2012; Laut and Rodrigues, 2011) or other in coastal systems (e.g. Coccioni et al., 2009; Frontalini et al., 2009, 2010, 2011; Martins et al., 2010, 2011, 2013, 2015 b, c, d, 2016; Clemente et al., 2015).

In some layers of the core $\mathrm{T} 1$, the benthic foraminifera assemblages are small and composed of both calcareous and agglutinated species, such as between 195-175 cm. In these layers, species such as B. striatula, B. elegantissima coexist with A. mexicana. The increase of these species is related to the rise of TOC content in the period between $\approx 380-350 \mathrm{yrs} \mathrm{cal}$ BP. Thus these layers may represent paleoevents of increased supply of organic matter to the benthic environment and depleted oxygen in sedimentary pore-waters.

These species are known for their opportunistic behavior when the supply of organic matter increase and by their tolerance to low oxic conditions (Brönnimann et al., 1981 a, b; Sen Gupta and Machain-Castillo, 1993; Moodley et al., 1997, 1998; Semensatto-Jr et al., 2004; Laut et al., 2009). This is also a transitional assemblage from the essentially calcareous foraminifera assemblies developed in the period $\approx 1300-380$ yrs cal BP $(340-195 \mathrm{~cm})$ to the exclusively agglutinated microfauna that populated the area in the last $\approx 300 \mathrm{yrs}$ cal BP $(150-0 \mathrm{~cm})$.

The foraminifera assemblage of the last $\approx 300 \mathrm{yrs}$ cal BP $(150-0 \mathrm{~cm})$ includes species such as $A$. mexicana, E. macrescens, H. manilaensis, H. wilberti, $M$. fusca and T. inflata. The presence of these species and the absence of calcareous species in that layers are indicative of a typical mangrove fauna associated with a very high supply of organic matter, erratic and great oscillations of environmental parameters and high salinity values (Laut et al., 2006, 2011, 2012; Laut and Rodrigues, 2011; Murray and Alve, 2011; Camacho et al., 2015). According to the compilation of Murray (2006), these species are typical of saline swamps and mangroves. This feature was also observed by other authors (e.g. Zaninetti et al., 1979; Brönnimann et al., 1981b; Scott et al., 1990).

In the upper core section, the sediments are finer grained and display very high TOC content. These characteristics indicate an increase in the degree of confinement, which may also avoid the development of more sensitive species of benthic foraminifera to low oxic conditions and the excessive augment of salinity.

\subsection{Environmental changes in the last 2400 yrs cal BP}

The textural and compositional characteristics of the sediments, the abundance, specific richness and foraminifera assemblages composition in the core T1 indicate significant environmental changes along the last $2400 \mathrm{yrs}$ in the area occupied by the current Guaratiba Mangrove.

The tests of benthic foraminifera are absent or rare in the sediments deposited for instance between $\approx 2400-1400 \mathrm{yrs}$ cal BP $(480-350 \mathrm{~cm})$, around $\approx 250 \mathrm{yrs}$ cal BP $(130 \mathrm{~cm})$, between $\approx 200-150 \mathrm{yrs}$ cal BP $(95-75 \mathrm{~cm})$ and between $\approx 100$ 50 yrs cal BP $(55-30 \mathrm{~cm})$.

The sediments deposited in the period $\approx 2400-1400$ yrs cal BP $(480-350 \mathrm{~cm})$ are characterized by coarser grained particles, relatively low carbonates content, intermediate values of TOC and absent or rare foraminifera tests and mollusk remains. These characteristics agree with the prevalence of highest hydrodynamic conditions in the study area, which avoid the settlement of benthic foraminifera and mollusk populations.

Considering the studies performed by Roncarati and Barrocas (1978) and Roncarati and Carelli (2012), Sepetiba Bay should have been protected by the Marambaia sand ridge hereafter 3440 yrs cal BP.

The textural and compositional characteristics of the sediments deposited in the period $\approx 2400-1900$ yrs cal BP $(480-415 \mathrm{~cm})$ indicate that the study area should belong to a sandy bank. This sandy bank should be located in an interface between a wavy breaking zone and a shoreface zone with periods of sub-aerial exposition and extended dryness.

The sediments deposited in the period $\approx 1400-300 \mathrm{yrs}$ cal BP $(350-150 \mathrm{~cm})$ are marked by the reduction of particles grain size, relatively low TOC and carbonates content and highest foraminifera density and diversity, as well as relatively abundant shells and bioclasts of mollusks. Foraminifera assemblages in this period are composed mostly of calcareous species, such as $A$. parkinsoniana, $A$. tepida, Ammonia sp., C. excavatum, C. poeyanum, E. gunteri, Elphidium $\mathrm{sp}$. and $H$. germanica. These species are common in worldwide transitional coastal environments (Murray 1991, 2006) and are quite common in the shallower environments of Sepetiba Bay (Zaninetti et al., 1977; Brönnimann et al., 1981 a, b; Laut et al., 2009, 2012). This benthic foraminifera assemblage indicates that the studied area undergone immersion in the 
period between $\approx 1400$ and $300 \mathrm{yrs}$ cal BP. This illation is also supported by the values of $\mathrm{C} / \mathrm{S}$ ratio (Fig. 9) in this period, which are similar to that commonly found in marine sediments (Morse and Emeis, 1990).

However, the results of ${ }_{A . t e p i d a} \delta{ }^{18} \mathrm{O}$ and ${ }_{\text {A.tepidd }}{ }^{13} \mathrm{C}$ display some oscillations in the period $\approx 1400-300$ yrs cal BP (350$150 \mathrm{~cm}$ ). The increasing of A.tpida $\delta^{18} \mathrm{O}$ values should be related to the influence of colder marine waters. These events are also positively correlated with ${ }_{\text {A.tepida }}{ }^{13} \mathrm{C}$ values linked probably with a relatively high contribution of organic carbon from marine biological productivity. In fact, the range of ${ }_{A \text { ttepidd }} \delta^{13} \mathrm{C}$ values obtained in the core $\mathrm{T} 1$ is similar to that found in living specimens of $A$. parkinsoniana in Bizerte Lagoon (Martins et al. 2016). In that lagoon, the organic matter supplied to the benthic communities seems to be mainly provided by the lagoonal biological productivity with a less expressive contribution from terrestrial sources (Martins et al., 2016).

However the results of ${ }_{A . t e p i d a} \delta^{18} \mathrm{O}$ obtained in the core T1 are much lower than that obtained by Martins et al. (2016) in Bizerte Lagoon. This difference should be related to further continental imprint of the Guaratiba Mangrove than Bizerte Lagoon, which is highly influenced by Mediterranean waters. Guaratiba Mangrove is influenced by Piracão and Piraquê rivers, as well as by the low salinity plume from other rivers runoff that flow into Sepetiba Bay. In the Tunisian lagoon, the rivers are small and with much more seasonal discharges due to the semi-desert climatic characteristics of that region, which make the Mediterranean water a very important influence in this system.

Thus, the results of ${ }_{\text {A.tepida }} \delta^{18} \mathrm{O}$ and ${ }_{A . t a p i d a} \delta^{13} \mathrm{C}$ indicate a marine influence in the period $\approx 1400-300$ yrs cal BP (350$150 \mathrm{~cm}$ ). These events should be related to phases with stronger marine water incursion into the study area.

The depth plot of the Factor Scores 1 and 2 along the core T1, foraminifera density, agglutinated species abundance and the values of the $\mathrm{C} / \mathrm{S}$ ratio presented in Figure 9 as well as the description of the other biotic and abiotic results help us to summarize the possible conditions that prevailed in the study area in the last $2400 \mathrm{yrs}$ cal BP. Results of Factor Score 1 suggest that the study area experienced wavy action and shoreface sub-aerial processes in the period between $\approx 2400-1400 \mathrm{yrs}$ cal BP. Later, between 1.400-300 yrs cal BP, the study area undergone submergence. The assemblages of foraminifera of this period are abundant and similar to that found in present shallow and protected bottom environments of Sepetiba Bay. The immersion phase was more marked between $\approx 850-380 \mathrm{yrs}$ cal BP and evolved during the last $\approx 350 \mathrm{yrs}$ cal BP to the current characteristics of the Guaratiba Mangrove region. This mangrove environment seems to have been kept in the $\approx$ last $100 \mathrm{yrs}$ cal BP.

The reasons of this immersion phase in this region is not yet well understood. It should be related to a small oscillation of sea level induced by climatic oscillations (at the edge of the Medieval Warm Period and the Little Ice Age) and by the evolution of Marambaia sand ridge. The most significant regressive event since the maximum Holocene higher sea level (recorded at about 5100 yrs BP) occurred up to 2400 yrs cal BP, according to Pereira and Santos (2012) based on sedimentological and biogenic (mollusks) records in the study region. Thenceforward, the sea level has been a trend to rise with small oscillations (Pereira and Santos, 2012). A possible rupture of the Marambaia sand ridge may be suggested too for the submergence of the study area in the period $\approx 1400-300 \mathrm{yrs}$ cal BP. This sandy spit broke several times in the past (Roncarati and Barrocas, 1978; Roncarati and Carelli, 2012). The ancient development of the Guaratiba Mangrove region needs to be further studied aiming to obtain a best temporal accuracy and definition of the events that marked its past evolution. This area outstands due to both their environmental particular characteristics (a nursery and protected area for fishes and other organisms) and its link with the Marambaia sand ridge, which protect the Sepetiba Bay.

\section{CONCLUSIONS}

Species richness and benthic foraminifera density and assemblages composition as well as the analyzed abiotic variables indicate that the depositional environment of the Sepetiba salt-march changed significantly in the last $2400 \mathrm{yrs}$ cal BP.

Our results indicate that: i) the period between $\approx 2400$ 1400 yrs cal BP, the study area should have been submitted to coastal waves followed by sub-aerial exposition and extended dryness; ii) between $\approx 1400-300$ yrs cal BP, the study area was exposed to marine processes, this is, became a transitional shallow transitional environment similar to that found nowadays in Sepetiba Bay; iii) this environment evolved since the last $\approx 350 \mathrm{yrs}$ cal $\mathrm{BP}$ to the present mangrove environment.

\section{Acknowledgments}

The authors thanks to the Editor and the reviewers of JSE. This paper is a contribution of a project of Fundação Carlos Chagas Filho de Amparo à Pesquisa do Estado do Rio de Janeiro (FAPERJ; process \# APQ1 E26/111.398/2014). The first author 
thanks to the fellowship provided by Conselho Nacional de Desenvolvimento Científico e Tecnológico (CNPq). The authors also would like to Nelson José Marques of LGQM-UERJ and Gabriela Valdes of LGPA-UERJ and the team of Laboratório de Oceanografia Geológica da Faculdade de Oceanografia-UERJ.

\section{References}

Andrade, A. C. S., Dominguez, J. M. L., 2003. Origem e evolução do sistema ilha barreira / laguna holocênico da planície costeira de Caravelas - Bahia - Brasil. In: Anais do Congresso da Associação Brasileira de Estudos do Quaternário, Abequa, Recife, 9, Cd-Rom.

Angulo, R.J., Lessa, G.C., Souza, M.C., 2006. A critical review of mid- to late-Holocene sea-level fluctuations on the eastern Brazilian coastline. Quaternary Science Review 25, 486-506.

Angulo, R.J., Isla, F.I., Schnack, E.J., Souza, M.C., 1999. A review of Holocene sea-level curves from the southwest Atlantic Ocean. In: Fletcher, C.H., Matthews, J.V. (eds.), The Non-steady State of the Inner Shelf and Shoreline: Coastal Change on the Time Scale of Decades to Millennia in the Late Quaternary. Inaugural Meeting of IGCP Project \#437 "Coastal Environmental Change During Sea Level Highstands”, Honolulu, Hawaii, Abstracts with Programs, pp. 35-36.

Angulo, R.J., Lessa, G., 1997. The Brazilian sea level curves: a critical review with emphasis on the curves from Paranaguá and Cananéia regions. Marine Geology 140, 141-166.

Angulo, R.J., Suguio, K., 1995. Re-evaluation of the maxima of the Holocene sea-level curve for the State of Paraná, Brazil. Palaeogeography, Palaeoclimatlogy Palaeoecology 112, 385-393.

Angulo, R. J. 1993. Indicadores biológicos de paleoníveis marinhos na costa paranaense. Boletim Paranaense de Geologia 41, 1-34.

Barreto, A.M.F., Bezerra, F.H.R., Suguio, K., Tatumi, S.H., Yee, M., Paiva, R., Munita, C.S., 2002. Late Pleistocene marine terrace deposits in northeastern Brazil: sea-level changes and tectonic implications. Palaeogeography, Palaeoclimatlogy Palaeoecology 179, 57-69.

Bezerra, F.H.R., Barreto, A.M.F., Suguio, K., 2003. Holocene sea level history on the Rio Grande do Norte State coast, Brazil. Marine Geology 196, 73-89.

Bezerra, F.H.R., Amaro, V.E., Vita-Finzi, C., Saadi, A., 2001. Pliocene-Quaternary fault control of sedimentation and coastal plain morphology in NE Brazil. Journal South American Earth Science 14, 61-75.

Bezerra, F.H.R., Vita-Finzi, C., 2000. How active is a passive margin? Paleoseismicity in northeastern Brazil. Geology 28, $591-$ 594.

Bhatt, N., Bhonde, U., 2006. Geomorphic expression of late Quaternary sea level changes along the southern Saraushtra coast, west India. Journal Earth System Science 115, 395-402

Brönnimann, P., Moura, J.A., Dias-Brito, D., 1981a. Estudos Ecológicos na Baía de Sepetiba, Rio de Janeiro, Brasil: Foraminíferos. In: Anais do Congresso Latino-Americano de Paleontologia. Porto Alegre, pp. 878-891.

Brönnimann, P., Moura, J.A., Dias-Brito, D., 1981b. Estudos Ecológicos na Baía de Sepetiba, Rio de Janeiro, Brasil:
Foraminíferos. In: Anais do Congresso Latino-Americano de Paleontologia, Porto Alegre, pp. 862-865.

Camacho, S.G., Moura, D.M.J., Connor, S., Scott, D.B., Boski, T., 2015. Taxonomy, ecology and biogeographical trends of dominant benthic foraminifera species from an AtlanticMediterranean estuary (the Guadiana, southeast Portugal). Palaeontologia Electronica 18.1.17A, 1-27.

Carson, B.E., Francis, J.M. Leckie, R.M. Droxler, A.W. Dickens, G.R., Jorry, S.J., Bentley, S.J. Peterson, L.C., Opdyke, BN., 2008. Benthic Foraminiferal response to sea level change in the mixed siliciclastic-carbonate system of southern Ashmore Trough (Gulf of Papua). Journal of Geophysical Research 113, F01S20. doi:10.1029/2006JF000629.

Castro, J.W.A., Suguio, K., Seoane, J.C.S., Cunha, A.M., Dias, F.F., 2014. Sea-level fluctuations and coastal evolution in the state of Rio de Janeiro, southeastern Brazil. Anais da Academia Brasileira de Ciências 86(2), 671-683.

Castro, J.W.A., Suguio, K. 2010. Holocene and Late Pleistocene Relative Sea Level Fluctuations in Cabo Frio Island, Rio de Janeiro State - Brazil. In: Congrès Français de Stratigraphie, 4, Strati, Paris (France), pp. 58-61.

Castro, J.W.A., Senra, M.C.E., Ramos, R.R.C., 2009. Coquinas da Paleolaguna da Reserva Tauá - Pântano da Malhada, RJ - Um Registro do Optimum Climático Holocênico. In: Winge, M., Schobbenhaus, C., Berbert-Born, M., Queiroz, E.T., Campos, D.A., Souza, C.R.G., Fernandes, A.C.S. (eds.). Sítios Paleontológicos do Brasil. CPRM, 2. 515 pp. (http://sigep.cprm.gov.br/sitio004/sitio004.pdf)

Church, J.A., White, N.J., Konikow, L.F., Domingues, C.M., Cogley, J.G., Rignot, E., Gregory, J.M., van den Broeke, M.R., Monaghan, A.J., Velicogna, I., 2011. Revisiting the Earth's sealevel and energy budgets from 1961 to 2008. Geophysical Research Letters 38, L18601. doi.10.1029/2011GL048794

Church, J. A., Woodworth, P.L., Aarup, T., Wildon, W.S., 2010: Understanding Sea-Level Rise and Variability, 428 pp.

Clemente, I.M.M.M., Silva, F.S., Laut, L.L.M., Frontalini, F., Costa, V.C., Rodrigues, M.A.C., Pereira, E., Bergamaschi, S., Mendonça Filho, J.G., Martins, M.V.A., 2015. Bottom Sector Environments in Guanabara Bay (Rio de Janeiro, Brazil). Journal of Coastal Research, $31 \quad$ (5), 1190-1204. doi: http:/ /dx.doi.org/10.2112/JCOASTRES-D-14-00104.1

Coccioni, R., Frontalini, F., Marsili, A., Mana, D., 2009. Benthic foraminifera and heavy metal distribution: A case-study from the heavily polluted lagoon of Venice (Italy). Marine Pollution Bulletin 59, 257-267.

Costa, J.B.S., Bemerguy, R.L., Hasui, Y., Borges, M.S., 2001. Tectonics and paleogeography along the Amazon River. Journal of South America Earth Science 14, 335-347.

Craig, H., 1957. Isotopic standards for carbon and oxygen and correction factors for mass spectrometric analysis of carbon dioxide. Geochemica Cosmochimica Acta 12, 181-186.

Cushman, J.A., Brönnimann, P., 1948 a. Additional New Species of Arenaceous Foraminifera from the Shallow Waters of Trinidad. Cushman Laboratory of Foraminiferal Research, Contribution 24, 37-42. 
Cushman, J. A., Brönnimann, P., 1948 b. Some New Genera and Species of Foraminifera from Brackish Water of Trinidad. Cushman Laboratory of Foraminiferal Research, Contribution 24, 15-22.

Debenay, J.-P., Bénéteau, E., Zhang, J., Stouff, V., Geslin, E., Redois, F., Fernandez-Gonzalez, M., 1998. Ammonia beccarii and Ammonia tepida (Foraminifera): Morphofunctional arguments for their distinction. Marine Micropaleontology 34, 235-244.

Fernandes, A.C.S., Borghi, L., Carvalho, I.S.E., Abreu, C.J., 2002. Estruturas de Bioerosão. In: Carvalho, I.S., Fernandes, A.C.S. Guia dos Icnofósseis Invertebrados do Brasil. 1. ${ }^{a}$ Ed. Rio de Janeiro, Interciências, 193 pp.

Figueiredo Jr., A.G., Duque, H.R., Ivo, F.C., Guiro, P.P., Gallea, G.G., Borges, H.V., 1989. Estratigrafia Rasa, Baía de Sepetiba RJ. In: Anais do Congresso da Sociedade de Geofísica, 1, Rio de Janeiro, pp. 786-792.

Fisher, R.A., Corbet, A.S., Williams, C.B., 1943. The relation between the number of species and the number of individuals in a random sample of an animal population. Journal of Animal Ecology 12, 42-58.

Flexor, J.M., Martin, L., Suguio, K., Domingues, J.M.L., 1984. Gênese dos cordões litorâneos da parte central da Costa Brasileira. In: Lacerda, L.D., Araújo, D.S.D., Cerqueira, R. and Turcq B. (orgs.), Restingas: Origem, Estrutura, Processos. Universidade Federal Fluminense, Niterói, pp. 35-46.

Folk, R.L., Ward, W.C., 1957. Brazos River bar: a study in the significance of grain size parameters. Journal of Sedimentary Petrology 27, 3-26.

Frontalini, F., Coccioni, R., 2011. Benthic foraminifera as bioindicators of pollution: a review of Italian research over the last three decades. Revieu de Micropaleontology 54, 115-127.

Frontalini, F., Coccioni, R., Bucci C., 2010. Benthic foraminiferal assemblages and heavy metal contents from the lagoons of Orbetello and Lesina. Environmental Modelling Assessement 170, 245-260.

Frontalini, F., Buosi, C., Da Pelo, S., Coccioni, R., Cherchi, A., Bucci, C., 2009. Benthic foraminifera as bio-indicators of heavy metal pollution in the heavily contaminated Santa Gilla lagoon (Cagliari, Italy). Marine Pollution Bulletin 58, 858-877.

Heilbron, M., Machado, N., 2003. Timing of terrene accretion in the Neoproterozoic-Eopaleozoic Ribeira orogen (SE Brazil). Precambrian Research 125, 87-112.

Horton, B.P., Culver, S.J., Hardbattle, M.I.J., Larcombe, P., Milne, G.A., Morigi, C., Whittaker, J.E., Woodroffe, S.A., 2007. Reconstructing Holocene sea-level change for the central Great Barrier Reef (Australia) using subtidal foraminifera. Journal of Foraminiferal Research 37, 47-63.

IPCC (Intergovernmental Panel on Climate Change), 2014. Climate Change 2014: Impacts, Adaptation, and Vulnerability. Report. http://ipcc.ch/report/ar5/wg2/

Kohn, M.J., Riciputi, L.R., Stakes, D., Orange, D.L., 1998. Sulfur isotope variability in biogenic pyrite: Reflections of heterogeneous bacterial colonization? American Mineralogist 83, 1454-1468.

Laborel, J., 1986. Vermetid gastropods as sea-level indicators. In: Van de Plassche, O. (ed.), Sea-level research: a manual for the collection and evaluation of data. Norwich, Geo Books, pp. 281310.

Laut, L.L.M., Martins, M.V.A., Silva, F.S., Crapez, M.A.C., Fontana, L.F., Carvalhal-Gomes, S.B.V., Souza, R.C.C.L., 2016. Foraminifera, thecamoebians, and bacterial activity in polluted intertropical and subtropical Brazilian estuarine systems. Journal of Coastal Research 32, 56 - 69. doi:10.2112/JCOASTRES-D14-00042.1

Laut, L.L.M., Cabral, I.A., Rodrigues, M.A.C., Silva, F.S., Martins, M.V.A., Boski, T., Gomes, A.I., Dias, J.M.A., Fontana, L.F., Laut, V.M., Mendonça-Filho, J.G., 2014. Compartimentos Ambientais do Estuário do Rio Arade, Sul de Portugal, com Base na Distribuição e Ecologia de Foraminíferos. Anuário do Instituto de Geociências - UFRJ, 38 (2), 115-126.

Laut, L.L.M., Silva, F.S., Martins, V., Rodrigues, M.A.C., Mendonça, J.O., Clemente, I.M.M.M., Laut, V.M., Mentzigen, L.G., 2012. Foraminíferos do Complexo Sepetiba/Guaratiba. In: Rodrigues, M.A.C, Pereira, S.D, Santos, S.B. (eds.), Baía de Sepetiba: Estado da Arte. Rio de Janeiro, Corbã, pp 115-150.

Laut, L.M., Rodrigues, M.A.C., 2011. Foraminíferos do manguezal de Guaratiba, Rio de Janeiro: Revisão taxonômica e aplicação de análises multivariadas. In: Carvalho, I. et al. (eds), Paleontologia: Cenários da Vida. Rio de Janeiro, Interciência, 3, 231-240.

Laut, L.L.M., Rodrigues, M.A.C., Clemente, I.M.M.M., Mentizigen, L.G., Pinheiro, M.P., 2009. Paleoecologia de foraminíferos bentônicos do Quaternário da Baía de Sepetiba, Rio de Janeiro Brasil. In: Boski, T., Moura, D., Gomes, A. (eds.), VII Reunião do Quaternário Ibérico, O futuro do ambiente da Península Ibérica: as lições do passado geológico recente, Universidade do Algarve, Faro, pp. 1001-105.

Laut, L.L.M., Koutsoukos, E.M.A., Rodrigues, M.A.C., 2006. Review of mangrove foraminífera from Guaratiba tidal plain, Rio de Janeiro, SE Brazil collected in the early 70's. Anuário do Instituto de Geociências- UFRJ, 29, 427-428.

Leckie, R.M., Olson, H.C., 2003. Micropaleontologic proxies for sea-level change and stratigraphic discontinuities. In: Olson, H.C., Leckie, R.M. (eds.), SEPM Special Publication 75, 5-19.

Lessa, G.C., Angulo, R.J., 1998. Oscillations or not oscillations, that is the question-reply. Marine Geology 150, 189-196.

Li, F., Rong, X., Meixun, Z., Liping, Z., Jianguo, L., Lanlan, Z., 2013. Phase Evolution of Holocene Paleoenvironmental Changes in the Southern Yellow Sea: Benthic Foraminiferal Evidence from Core C02. Oceanic and Coastal Sea Research 12, 629-638.

Loeblich, A.R. Jr., Tappan, H., 1988. Foraminiferal Genera and Their Classification. New York, Van Nostrand Reinhold Company.

Machado, N., Valladares, C., Heilbron, M., Valeriano, C., 1996. U$\mathrm{Pb}$ geochronology of the Central Ribeira Belt (Brazil) and implications for the evolution of the Brazilian Orogeny. Precambrian Research 79, 347-361.

Martin, L., Suguio, K., Domingues, J.M.L.E., Flexor, J.M., 1997. Geologia do Quaternário costeiro do Litoral Norte do Rio de Janeiro e Espírito Santo.First Edition, Belo Horizonte, CPRM, $112 \mathrm{pp}$. 
Martin, L., Suguio, K., Flexor, J.M., 1986. Shell middens as a source for additional information in Holocene shoreline and sea-level reconstruction: examples from the coast of Brazil. In: Van de Plasseche, O. (ed.), Sea-Level Research: A Manual for the Collection and Evaluation of Data. Free University of Amsterdam, Amsterdam, pp. 503-521.

Martin, L., Flexor, J.-M., Blitzkow, D., Suguio, K., 1985. Geoid change indication along the Brazilian coast during the last 7,000 years. In: Proceedings of IGCP, Project 200, Coral Reef Congress, Tahiti, 3, 85-90.

Martin, L., Flexor J.M., Suguio, K., 1984. Enregistrement des périodes de fortes et faibles énergies à l'embouchure d'un fleuve. Le cas du Paraíba do Sul (Brésil). Implications paléoclimatiques. Comptes Rendus de l'Académie des Sciences - Series II A 299, 661-664.

Martins, M.V.A., Helali, M.A., Zaaboub, N., Boukef-BenOmrane, I., Frontalini, F., Reis, D., Portela, H., Clemente, I.M.M.M., Nogueira, N., Pereira, E., Miranda, P., Aleya, L., El Bour, M., 2016. Organic matter quantity and quality, metals availability and foraminifera assemblages as environmental proxy applied to the Bizerte Lagoon (Tunisia). Marine Pollution Bulletin, doi.org/10.1016/j.marpolbul.2016.02.032

Martins, M.V.A., Mane, M.A., Frontalini, F., Santos, J.F., Silva, F.S., Terroso, D., Miranda, P, Figueira, R., Laut, L.L.M., Bernardes, C., Filho, J.G.M., Coccioni, R., Rocha, F., 2015a. Early diagenesis and adsorption by clay minerals important factors driving metal pollution in sediments. Environmental Science and Pollution Research 22, 10019-10033. doi: 10.1007/s11356-015-4185-4.

Martins, V.A., Silva, F., Lazaro, L.M.L., Frontalini, F., Clemente, I.M., Miranda, P., Figueira, R., Sousa, S.H.M., Dias, J.M.A., 2015b. Response of benthic foraminifera to organic matter quantity and quality and bioavailable concentrations of metals in Aveiro Lagoon (Portugal). PLoS ONE 10 (2): e0118077. doi:10.1371/journal.pone.0118077

Martins, V.A., Laut, L.L.M., Silva, F.S., Miranda, P., MendonçaFilho, J.G., Fernández-Fernández, S., Sousa, S.S., Rodrigues, M.A.C., Rodrigues, A.R., Yamashita, C., Faria, E.O., Oliveira R.R., Nagai, R.H., 2015c. Associações de foraminíferos em resposta a variações ambientais da Laguna de Aveiro - Portugal. Anuário de Geociências - UFRJ, 38, 56-69. doi.org/10.11137/2015_2_56_69

Martins, M.V.A. Zaaboub, N., Aleya, L., Frontalini, F., Pareira, E., Miranda, P., Mane, M., Rocha, F., Laut, L., El Bour, M. 2015d. Environmental quality assessment of Bizerte Lagoon (Tunisia) using living foraminifera assemblages and a multiproxy approach. PLoS ONE. doi.10.1371/journal.pone.0137250

Martins, MVA, Frontalini, F., Rodrigues, M.A.C., Dias, J.A., Laut, L.L.M., Silva, F.S., Clemente, I.M.M.M., Reno, R., Moreno, J., Sousa, S., Zaaboub, N., El Bour, M., Rocha, F., 2014. Foraminiferal biotopes and their distribution control in Ria de Aveiro (Portugal): a multiproxy approach. Environmental Monitoring and Assessment 186, 8875-8897. doi: 10.1007/s10661-014-4052-7

Martins, M.V.A., Frontalini, F., Tramonte, K.M., Figueira, R.C.L., Miranda, P., Sequeira, C., Fernández-Fernández, S., Dias, J.A.,
Yamashita, C., Laut, L.M., Silva, F.S., Rodrigues, M.A.C., Bernardes, C., Nagai, R., Sousa, S.M., Mahiques, M., Rubio, B., Bernabeu, A., Rey, D., Rocha, F., 2013. Assessment of the health quality of Ria de Aveiro (Portugal): heavy metals and benthic foraminifera. Marine Pollution Bulletin 70, 18-33. doi.org/10.1016/j.marpolbul.2013.02.003.

Martins, V., Yamashita, C., Sousa, S.H.M., Martins, P., Laut, L.L.M., Figueira, R.C.L., Mahiques, M.M., Ferreira da Silva, E., Dias, J.M.A., Rocha, F., 2011. The response of benthic foraminifera to pollution and environmental stress in Ria de Aveiro (N Portugal). Journal of Iberian Geology 37, 231-246. doi: 10.5209/rev_JIGE.2011.v37.n2.10.

Martins, V., Ferreira da Silva, E., Sequeira, C., Rocha, F., Duarte, A.C., 2010. Evaluation of the ecological effects of heavy metals on the assemblages of benthic foraminifera of the canals of Aveiro (Portugal). Estuarine, Coastal and Shelf Science 87, 293 304. doi:10.1016/j.ecss.2010.01.011

Milne, G. A., Gehrels, W.R., Hughes, C. W., Tamisiea, M. E., 2009. Identifying the causes of sea-level change. Nature Geoscience 2, 471-478.

Moodley, L., Zwaan, G.L., Rutten, G.M.W., Boom, R.C.E., Kempers, A.J., 1998. Subsurface activity of benthic foraminifera in relation to pore water oxygen content: laboratory experiments. Marine Microplaleontology 34, 91-106.

Moodley, L., van der Zwaan, G.J., Herman, P.M.J., Kempers, L., van Breugel, P., 1997. Differential response of benthic meiofauna to long-term anoxia with special reference to Foraminifera (Protista: Sarcodina). Marine Ecology Progress Series 158, 151-163.

Moraes-Neto, J.M., Alkimim, F.F., 2001. A deformação das coberturas terciárias do planalto da Borborema (PB-RN) e seu significado tectônico. Revista Brasileira de Geociências 31, 95 106.

Morse, I.W., Emeis, K.C., 1990. Controls on C/S ratios in hemipelagic upwelling sediments. American Journal of Science, 290, 117-1135.

Murray, J.W., Alve, E., 2011. The distribution of agglutinated foraminifera in NW European seas: Baseline data for the interpretation of fossil assemblages. Palaeontologia Electronica 14.2.14A, $41 \mathrm{pp}$

Murray, J.W., 2006. Ecology and Applications of Benthic Foraminifera. Cambridge University Press, 426 pp.

Murray, J.W., 1991. Ecology and palaeoecology of benthic foraminifera. London, Longman Scientific and Technical, 397 pp.

Nooijer, L.J., Toyofuku, T., Kitazato, H., 2009. Foraminifera promote calcification by elevating their intracellular $\mathrm{pH}$. PNAS, Proceedings of the National Academy of Sciences 106(36), 15374-15378. doi:10.1073/pnas.0904306106

Pereira, S.D., Santos, S.B., 2012. Restos de moluscos na Baía de Sepetiba como indicadores de alterações pretérias da linha de costa no Holoceno. In: Rodrigues, M.A.C., Pereira, S.D., Santos, S.B. (eds.), Baia de Sepetiba estado da Arte, Corbã, Rio de Janeiro, pp. 105-111. 
Pereira, S.D., Chaves, H.A.F., Coelho, L.G., 2009. The little ice age in the region of the Sepetiba Bay, Rio de Janeiro - Brazil. Journal of Coastal Research SI 56, 252-256.

Pereira, S.D., Chaves, H.A.F., Santos, S.B., 2007. Evidence of sea level change at Guaratiba Mangrove, Sepetiba Bay, Brazil.

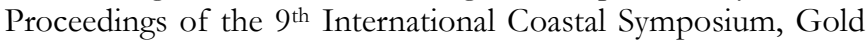
Coast, Australia, pp. 1097-1100.

Pirazzoli, P.A., Delibrias, G., Kawana, T., Yamaguchi, T., 1985. The use of barnacles to measure and date relative sea-level changes in the Ryukyu islands, Japan. Palaeogeography, Palaeoclimatology, Palaeoecology 49, 161-174.

Reimer, P.J., Bard, E., Bayliss, A., Beck, J.W., Blackwell, P.G., Ramsey, C.R., Buck, C., Cheng, H., Edwards, R.L., Friedrich, M., Grootes, P.M., Guilderson, T.P., Haflidason, H., Hajdas, I. Hatté, C., Heaton, T.J., Hoffmann, D.L., Hogg, A.G., Hughen, K.A., Kaiser, K.F., Kromer, B., Manning, S.W., Niu, M., Reimer, R.W., Richards, D.A., Scott, E.M., Southon, J.R., Staff, R.A., Turney, C.S.M., van der Plicht, J., 2013. IntCal13 and Marine13 Radiocarbon Age Calibration Curves 0-50,000 Years cal BP. Radiocarbon 55, 1869-1887.

Romahn, S., Mackensen, A., Kuhlmann, H., Pätzold, J., 2015. Benthic foraminiferal response to Late Glacial and Holocene sea level rise and rainfall variability off East Africa. Marine Micropaleontology 119, 34-48.

Roncarati, H., Carelli, S.G., 2012. Considerações sobre o estado da arte dos processos geológicos Cenozóicos atuantes na Baía de Sepetiba. In: Rodrigues, M.A.C, Pereira, S.D, Santos, S.B. (eds.), Baía de Sepetiba: Estado da Arte. Rio de Janeiro, Corbã, pp. 1336.

Roncarati, H., Barrocas, S.L.S., 1978. Estudo geológico preliminar dos sedimentos recente superficiais da Baía de Sepetiba, Município do Rio de Janeiro, Itaguaí e Mangaratiba, RJ. (Projeto Sepetiba). Rio de Janeiro, Petrobrás, CENPES, 78 pp.

Roncarati, H., Neves, L.E., 1976. Estudo preliminar dos sedimentos recentes superficiais da Baixada de Jacarepaguá Município do Rio de Janeiro (Projeto Jacarepaguá). Rio de Janeiro, Petrobrás, CENPES, 89 pp.

Rossetti, D.F., Valeriano, M.M., Góes, A.M., Thalles, M., 2008a. Palaeodrainage on Marajó Island, northern Brazil, in relation to Holocene relative sea-level dynamics. Holocene 18, 1-12.

Rossetti, D.F., Góes, A.M., Valeriano, M.M., Miranda, M.C., 2008b. Quaternary tectonics in a passive margin: Marajó Island, northern Brazil. Journal Quaternary Science 23, 121-135.

Rouchy, J.M., Taberner, C., Peryt, T.M., 2001. Sedimentary and diagenetic transitions between carbonates and evaporites. Sedimentary Geology 140, 1-8.

Saunders, J.A., Pritchett, M.A., Cook, R.B., 1997. Geochemistry of biogenic pyrite and ferromanganese coatings from a small watershed: A bacterial connection? Geomicrobiology Journal 14, 203-217.

Schröder, C.J., Scott, D.B., Mediolli, F.S. 1987. Can smaller benthic foraminifera be ignored in paleoenvironmental analyses? Journal of Foraminiferal Research 4, 101-110.
Scott, D.B., Medioli, F.S., Schafer, C.T., 2001. Monitoring in coastal environments using foraminifera and thecamoebia indicators. Cambridge, Cambridge University Press, 177 pp.

Scott, D.B., Schnack, E.J., Ferrero, L., Espinosa, M., Barbosa, C.F., 1990. Recent Marsh Foraminifera from the East Coast of South America: Comparison to the Northern Hemisphere. In: Hemleben et al. (eds.), Paleoecology, Biostratigraphy, Paleooceanography, and Taxonomy of agglutinated foraminifera, Kluwer Academic Publishers, Netherlands, Proceedings of NATO ASI/Series C, pp. 717-738.

SEMA, ZEE-RJ, 1996. Programa de zoneamento econômicoecológico do estado do Rio de Janeiro. Projeto 1: diagnótistico ambiental da bacia hidrágráfica da Baía de Sepetiba. Rio de Janeiro, Secretaria de Estado de Meio Ambiente, Universidade Federal do Rio de Janeiro, Empresa Brasileira de Pesquisa Agropecuária.

Semensatto-Jr, D.L., Dias-Brito, D., 2004. Análise Ambiental de uma área parálica no delta do Rio São Francisco, Sergipe-Brasil, com base na sinecologia de foraminíferos e tecamebas (Protista). Revista Brasileira de Paleontologia 7, 53-66.

Sen Gupta, B.K., Machain-Castillo, M.L., 1993. Benthic foraminifera in oxygen-poor habitats. Marine Micropaleontology 20, 183-201.

Strachan, K.L., Finch, J.M., Hill, T., Barnett, R.L., 2014. A late Holocene sea-level curve for the east coast of South Africa. South African Journal of Science 110, 1-9.

Suguio, K., Angulo, R.J., Carvalho, A.M., Corrêa, I.C.S., Tomazelli, L.J., Vital, H., 2005. Paleoníveis do Mar e Paleolinhas de Costa. In: Oliveira, A.M., Souza,C.R.G.S., Suguio, K., Oliveira, P.E. (eds.), Quaternário do Brasil. First edition, Holos Editora, Ribeirão Preto, pp.114-129.

Suguio, K., 2003a. Geologia Sedimentar. First edition, Editora Edgard Blücher, São Paulo, 324 pp.

Suguio, K., 2003b. Tópicos de geociências para o desenvolvimento sustentável: as regiões litorâneas. Boletim Geologia USP, Série Didática 2, 1-40.

Suguio, K. 1999. Geologia do Quaternário e Mudanças Ambientais (Passado + Presente $=$ Futuro?). First edition, Paulo's Comunicação e Artes Gráficas, São Paulo, 366 pp.

Suguio, K., Martin, L., Bittencourt, A.C.S.P., Dominguez, J.M.L., Flexor, J.M., Azevedo, A.E. G., 1985. Flutuações do nível relativo do mar durante o Quaternário superior ao longo do litoral brasileiro e suas implicações na sedimentação costeira. Revista Brasileira de Geociências 15, 273-286.

Suguio, K., Tessler, M.G., 1984. Planícies de cordões litorâneos quaternários do Brasil: origem e nomenclatura. In: Lacerda L.D., Araujo, D.S.D., Cerqueira R., Turcq, B. (eds.), Restingas: origem, estrutura, processos, CEUFF, Niterói, p. 15-25.

Suguio, K., Martin, L., 1978. Quaternary marine formations of the states of São Paulo and southern Rio de Janeiro. In: International Symposium On Coastal Evolution in The Quaternary. Special Publication. São Paulo, Brazilian National Working Group for the IGCP-Project 61, 1-55.

Talma, A.S., Vogel, J.C., 1993. A simplified approach to calibrate C14 dates. Radiocarbon 35, 317-322. 
Tinoco, I.M., 1965. Contribuição à sedimentologia e microfauna da Baía de Sepetiba (Estado do Rio de Janeiro). Recife: Instituto Oceanográfico, Universidade Federal de Pernambuco, 7/8, 123 135.

Tupinambá, M., Teixeira, W., Heilbron, M., 2000. Neoproterozoic Western Gondwana assembly and subduction-related plutonism: the role of the Rio Negro Complex in the Ribeira Belt, Southeastern Brazil. Revista Brasileira Geociências 30, 7-11.

Turcq, B., Martin, L., Flexor, J.L., Suguio, K., Pierre, C., TasayacoOrtega, L., 1999. Origin and evolution of the Quaternary coastal plain between Guaratiba and Cabo Frio, State of Rio de Janeiro. In: Knoppers, B.A., Bidone, E.D., Abrão, J.J. (eds.), Environmental Geochemistry of Coastal Lagoon Systems, Série Geoquímica Ambiental, EDUFF, Niterói, p.25-46.

Uehara, R.S., Duleba,W., Petri, S., Mahiques, M.M., Rodrigues, M., 2007. Micropaleontologia e Sedimentologia Aplicadas à Análise Paleoambiental: um Estudo de Caso em Cananéia, São Paulo, Brasil. Revista Brasileira de Paleontologia 10, 137-150.

Uthicke, S., Momigliano, P., Fabricius, K.E., 2013. High risk of extinction of benthic foraminifera in this century due to ocean acidification. Scientific Reports 3, 1769. doi:10.1038/srep01769
Villwock, J.A., 1994. A costa brasileira: geologia e evolução. Notas Técnicas - UFRGS 7, 38-49.

Warren, J.K., 1999. Evaporites. Their Evolution and Economics. Blackwell, Oxford (438 pp).

Warren, J.K., 1989. Evaporite Sedimentology. Prentice Hall Advanced Reference Series, Physical and Life Sciences. Prentice Hall, Englewood Cliffs, 285 pp.

Zaninetti, L., Brönnimann, P., Dias-Brito, D., Arai, M., Casaletti, P., Koutsoukos, E.A., Silveira, S., 1979. Distribution écologique des foraminifères dnas la mangrove d'Acupe, état de la Bahia, Brésil. Notes du Laboratoire de Paleontologie de l'Universite de Geneve, 4(1), 1-17.

Zaninetti, L., Brönnimann, P., Beurlen, G., Moura, J.A., 1977. La Mangrove de Guaratiba et la Baie de Sepetiba, État de Rio de Janeiro, Brésil: Foraminifères et écologie: Archieves des Science, 30, 161-178.

Zaninetti, L., Brönnimann, P., Beurlen, G., Moura, J.A., 1976. La Mangrove de Guaratiba et la Baie de Sepetiba, État de Rio de Janeiro, Brésil: Foraminifères et écologie. Note préliminaire. Archieves des Science 11, 39-44. 
Supplementary material 1. Sediment fractions, total organic carbon (TOC; \%), total sulfur S; \%); calcium carbonate (\%); species richness (SR; number of species per samples) and foraminifera density (Foram D; $\mathrm{n}^{\circ} / 10 \mathrm{ml}$ ).

\begin{tabular}{|c|c|c|c|c|c|c|c|c|c|c|c|c|c|c|c|}
\hline $\begin{array}{l}\text { Depth } \\
\text { (cm) }\end{array}$ & $\begin{array}{c}\text { Coarse } \\
\text { Sand }(\%)\end{array}$ & $\begin{array}{l}\text { Medium } \\
\text { Sand (\%) }\end{array}$ & $\begin{array}{c}\text { Fine } \\
\text { Sand }(\%)\end{array}$ & $\begin{array}{l}\text { Very Fine } \\
\text { Sand }(\%)\end{array}$ & $\begin{array}{l}\text { Very Coarse } \\
\text { Silt ( } \%)\end{array}$ & $\begin{array}{l}\text { Coarse } \\
\text { Silt }(\%)\end{array}$ & $\begin{array}{l}\text { Medium } \\
\text { Silt (\%) }\end{array}$ & $\begin{array}{c}\text { Fine Silt } \\
(\%)\end{array}$ & $\begin{array}{c}\text { Very Fine } \\
\text { Silt }(\%)\end{array}$ & $\begin{array}{l}\text { Clay } \\
(\%)\end{array}$ & $\begin{array}{c}\text { TOC } \\
(\%)\end{array}$ & $\begin{array}{c}\mathrm{S} \\
(\%)\end{array}$ & $\begin{array}{c}\mathrm{CaCO}_{3} \\
(\%)\end{array}$ & SR & Foram D \\
\hline 0.0 & 7.7 & 24.5 & 11.1 & 13.0 & 17.6 & 10.2 & 6.6 & 4.7 & 2.5 & 2.2 & 7.03 & 0.26 & 19 & 4 & 136 \\
\hline 10.0 & 18.2 & 23.3 & 23.1 & 15.6 & 8.6 & 4.8 & 2.9 & 2.0 & 1.1 & 0.4 & 2.66 & 0.12 & 22 & 11 & 144 \\
\hline 20.0 & 0.0 & 0.0 & 13.8 & 21.2 & 24.0 & 16.9 & 10.3 & 6.3 & 3.3 & 4.1 & 4.00 & 0.58 & 20 & 4 & 25 \\
\hline 30.0 & 6.3 & 20.9 & 19.1 & 21.2 & 16.7 & 8.2 & 3.8 & 1.9 & 1.0 & 0.8 & 3.56 & 0.42 & 18 & 0 & 0 \\
\hline 40.0 & 20.2 & 19.5 & 17.1 & 20.1 & 12.5 & 5.8 & 2.5 & 1.3 & 0.7 & 0.2 & 2.79 & 0.79 & 21 & 0 & 0 \\
\hline 55.0 & 22.8 & 14.6 & 19.0 & 21.2 & 12.0 & 6.3 & 2.5 & 1.0 & 0.4 & 0.1 & 2.97 & 0.94 & 22 & 0 & 0 \\
\hline 65.0 & 5.2 & 8.9 & 14.2 & 32.1 & 26.0 & 9.6 & 2.6 & 0.8 & 0.4 & 0.2 & 2.59 & 0.56 & 20 & 3 & 107 \\
\hline 75.0 & 20.4 & 27.0 & 20.9 & 15.6 & 9.2 & 4.6 & 1.5 & 0.6 & 0.2 & 0.0 & 2.50 & 0.96 & 23 & 0 & 0 \\
\hline 85.0 & 64.3 & 16.9 & 7.1 & 5.8 & 3.8 & 1.6 & 0.5 & 0.0 & 0.0 & 0.0 & 2.50 & 0.43 & 20 & 2 & 4 \\
\hline 95.0 & 10.8 & 2.8 & 13.1 & 33.2 & 26.6 & 1.0 & 5.6 & 3.1 & 1.6 & 2.0 & 2.28 & 0.69 & 18 & 1 & 2 \\
\hline 110.0 & 7.3 & 6.8 & 14.5 & 30.2 & 24.2 & 10.7 & 3.7 & 1.5 & 0.7 & 0.5 & 2.94 & 0.98 & 17 & 9 & 38 \\
\hline 120.0 & 30.6 & 24.8 & 16.8 & 14.8 & 1.1 & 6.7 & 2.9 & 1.3 & 0.7 & 0.2 & 2.52 & 0.59 & 21 & 1 & 2 \\
\hline 130.0 & 41.8 & 27.3 & 6.5 & 6.7 & 8.4 & 5.6 & 2.5 & 0.8 & 0.3 & 0.1 & 1.48 & 0.42 & 20 & 0 & 0 \\
\hline 140.0 & 24.6 & 27.6 & 15.9 & 12.2 & 9.3 & 5.6 & 2.5 & 1.3 & 0.6 & 0.1 & 1.33 & 0.70 & 20 & 3 & 3 \\
\hline 150.0 & 24.3 & 23.0 & 16.1 & 13.1 & 11.9 & 7.5 & 2.5 & 1.0 & 0.5 & 0.1 & 1.45 & 0.41 & 21 & 2 & 2 \\
\hline 165.0 & 15.8 & 23.7 & 19.9 & 17.3 & 10.8 & 6.5 & 3.2 & 1.7 & 0.9 & 0.2 & 1.45 & 0.41 & 21 & 8 & 96 \\
\hline 175.0 & 11.0 & 27.2 & 17.7 & 17.5 & 11.8 & 7.1 & 3.5 & 2.1 & 1.2 & 0.9 & 2.41 & 0.65 & 17 & 8 & 88 \\
\hline 185.0 & 12.1 & 17.9 & 18.5 & 26.7 & 15.2 & 5.7 & 2.3 & 1.0 & 0.5 & 0.1 & 1.20 & 0.57 & 10 & 9 & 204 \\
\hline 195.0 & 7.2 & 10.8 & 13.7 & 27.1 & 25.2 & 11.1 & 3.3 & 0.8 & 0.4 & 0.4 & 1.33 & 0.50 & 16 & 11 & 261 \\
\hline 205.0 & 18.6 & 18.7 & 10.4 & 19.3 & 18.2 & 8.9 & 3.4 & 1.6 & 0.7 & 0.3 & 1.25 & 0.64 & 15 & 5 & 118 \\
\hline 220.0 & 11.1 & 17.0 & 18.2 & 23.2 & 16.4 & 8.1 & 3.4 & 1.5 & 0.8 & 0.3 & 1.14 & 0.60 & 15 & 8 & 242 \\
\hline 230.0 & 0.0 & 0.4 & 6.2 & 21.7 & 29.1 & 23.8 & 9.7 & 4.3 & 2.0 & 3.0 & 1.29 & 0.55 & 16 & 8 & 218 \\
\hline 240.0 & 23.9 & 19.1 & 16.8 & 16.7 & 12.1 & 6.6 & 2.7 & 1.3 & 0.6 & 0.1 & 1.64 & 0.72 & 16 & 9 & 307 \\
\hline 250.0 & 47.5 & 15.4 & 6.8 & 8.5 & 9.8 & 6.8 & 2.9 & 1.2 & 0.4 & 0.6 & 0.97 & 0.53 & 14 & 9 & 317 \\
\hline 260.0 & 9.4 & 17.4 & 14.4 & 20.6 & 19.0 & 10.4 & 4.4 & 2.2 & 1.1 & 1.1 & 1.03 & 0.64 & 16 & 7 & 241 \\
\hline 275.0 & 14.9 & 7.8 & 10.2 & 18.2 & 20.7 & 15.0 & 6.9 & 3.0 & 1.3 & 1.9 & 1.00 & 0.43 & 18 & 8 & 315 \\
\hline
\end{tabular}




\section{ISE}

RESEARCH PAPER

Supplementary material 1 (cont.). Sediment fractions, total organic carbon (TOC; \%), total sulfur S; \%); calcium carbonate (\%); species richness (SR; number of species per samples) and foraminifera density (Foram D; $\mathrm{n}^{\circ} / 10 \mathrm{ml}$ ).

\begin{tabular}{|c|c|c|c|c|c|c|c|c|c|c|c|c|c|c|c|}
\hline $\begin{array}{l}\text { Depth } \\
\text { (cm) }\end{array}$ & $\begin{array}{c}\text { Coarse } \\
\text { Sand (\%) }\end{array}$ & $\begin{array}{l}\text { Medium } \\
\text { Sand (\%) }\end{array}$ & $\begin{array}{c}\text { Fine } \\
\text { Sand }(\%)\end{array}$ & $\begin{array}{l}\text { Very Fine } \\
\text { Sand }(\%)\end{array}$ & $\begin{array}{l}\text { Very Coarse } \\
\text { Silt }(\%)\end{array}$ & $\begin{array}{l}\text { Coarse } \\
\text { Silt (\%) }\end{array}$ & $\begin{array}{c}\text { Medium } \\
\text { Silt (\%) }\end{array}$ & $\begin{array}{c}\text { Fine Silt } \\
(\%)\end{array}$ & $\begin{array}{c}\text { Very Fine } \\
\text { Silt (\%) }\end{array}$ & $\begin{array}{l}\text { Clay } \\
(\%)\end{array}$ & $\begin{array}{c}\text { TOC } \\
(\%)\end{array}$ & $\begin{array}{c}S \\
(\%)\end{array}$ & $\begin{array}{c}\mathrm{CaCO}_{3} \\
(\%)\end{array}$ & SR & Foram D \\
\hline 285.0 & 0.9 & 10.0 & 17.2 & 43.0 & 21.8 & 5.3 & 1.2 & 0.4 & 0.2 & 0.1 & 0.94 & 0.42 & 18 & 9 & 321 \\
\hline 295.0 & 10.7 & 27.5 & 19.1 & 19.5 & 11.0 & 5.2 & 5.2 & 1.1 & 0.6 & 0.1 & 0.79 & 0.39 & 16 & 11 & 270 \\
\hline 305.0 & 16.3 & 11.9 & 16.4 & 27.8 & 16.1 & 6.7 & 2.5 & 1.2 & 0.6 & 0.2 & 0.62 & 0.37 & 12 & 8 & 325 \\
\hline 315.0 & 12.7 & 14.2 & 16.0 & 31.2 & 16.9 & 6.2 & 1.8 & 0.7 & 0.3 & 0.1 & 0.70 & 0.39 & 12 & 7 & 29 \\
\hline 330.0 & 18.0 & 15.8 & 14.8 & 22.1 & 11.7 & 7.0 & 4.2 & 3.1 & 1.9 & 1.4 & 0.75 & 0.38 & 13 & 0 & 0 \\
\hline 340.0 & 46.5 & 12.3 & 9.5 & 14.1 & 8.4 & 4.3 & 2.2 & 1.6 & 0.9 & 0.3 & 0.72 & 0.60 & 13 & 8 & 70 \\
\hline 350.0 & 48.6 & 21.2 & 9.7 & 9.4 & 5.3 & 2.7 & 1.3 & 0.9 & 0.6 & 0.1 & 1.24 & 0.68 & 15 & 0 & 0 \\
\hline 360.0 & 7.1 & 9.4 & 13.5 & 18.7 & 23.0 & 12.3 & 6.0 & 4.0 & 2.8 & 3.2 & 1.63 & 0.97 & 14 & 1 & 1 \\
\hline 370.0 & 41.1 & 21.9 & 13.3 & 9.8 & 6.6 & 3.4 & 1.7 & 1.1 & 0.7 & 0.2 & 1.51 & 0.75 & 12 & 0 & 0 \\
\hline 385.0 & 4.8 & 18.2 & 18.6 & 24.3 & 18.0 & 7.9 & 3.8 & 2.1 & 1.2 & 1.1 & 1.33 & 1.00 & 11 & 2 & 2 \\
\hline 395.0 & 12.3 & 19.9 & 8.4 & 16.5 & 18.6 & 10.6 & 5.8 & 3.5 & 2.2 & 2.1 & 1.48 & 0.87 & 14 & 0 & 0 \\
\hline 405.0 & 31.6 & 17.4 & 9.9 & 17.2 & 15.3 & 5.5 & 1.7 & 0.8 & 0.4 & 0.1 & 1.23 & 0.76 & 11 & 1 & 1 \\
\hline 415.0 & 23.2 & 26.3 & 15.0 & 15.5 & 12.6 & 4.9 & 1.5 & 0.7 & 0.4 & 0.1 & 2.68 & 0.77 & 13 & 0 & 0 \\
\hline 425.0 & 29.8 & 23.0 & 7.2 & 13.2 & 13.4 & 6.5 & 3.0 & 1.8 & 1.1 & 0.8 & 1.36 & 0.64 & 17 & 0 & 0 \\
\hline 440.0 & 52.7 & 35.4 & 3.2 & 1.0 & 3.0 & 3.2 & 1.0 & 0.3 & 0.1 & 0.0 & 1.59 & 0.83 & 12 & 0 & 0 \\
\hline 450.0 & 11.7 & 16.8 & 22.6 & 25.9 & 15.0 & 5.0 & 1.6 & 0.8 & 0.5 & 0.1 & 1.40 & 1.00 & 12 & 0 & 0 \\
\hline 460.0 & 0.6 & 3.6 & 5.1 & 14.8 & 26.3 & 18.7 & 10.4 & 8.0 & 6.0 & 6.5 & 1.32 & 0.45 & 15 & 0 & 0 \\
\hline 470.0 & 21.4 & 17.9 & 11.9 & 16.0 & 17.1 & 8.8 & 3.1 & 1.6 & 1.0 & 1.2 & 1.65 & 1.01 & 13 & 0 & 0 \\
\hline 480.0 & 9.1 & 8.6 & 6.8 & 14.1 & 22.2 & 16.1 & 7.9 & 5.8 & 4.5 & 4.8 & 1.52 & 1.13 & 12 & 0 & 0 \\
\hline Max. & 64.3 & 35.4 & 23.1 & 43.0 & 29.1 & 23.8 & 10.4 & 8.0 & 6.0 & 6.5 & 7.0 & 1.1 & 23.0 & 11.0 & 325.0 \\
\hline Min. & 0.0 & 0.0 & 3.2 & 1.0 & 1.1 & 1.0 & 0.5 & 0.0 & 0.0 & 0.0 & 0.6 & 0.1 & 10.0 & 0.0 & 0.0 \\
\hline
\end{tabular}


Supplementary material 2. Sediment mean grain size (SMGS; $\mu \mathrm{m}$ ) and other textural parameters along the core T1.

\begin{tabular}{|c|c|c|c|c|c|c|c|c|c|c|c|c|}
\hline $\begin{array}{l}\text { Depth } \\
\text { (cm) }\end{array}$ & $\begin{array}{l}\text { SMGS } \\
(\mu \mathrm{m})\end{array}$ & $\begin{array}{c}\text { Grain size } \\
\text { classification }\end{array}$ & $\begin{array}{c}\text { Mode } \\
1 \\
(\mu \mathrm{m}) \\
\end{array}$ & $\begin{array}{c}\text { Mode } \\
2 \\
(\mu \mathrm{m}) \\
\end{array}$ & $\begin{array}{c}\text { Mode } \\
3 \\
(\mu \mathrm{m}) \\
\end{array}$ & $\begin{array}{c}\text { Sorting } \\
(\sigma)\end{array}$ & $\begin{array}{l}\text { Skewness } \\
(\phi)\end{array}$ & $\begin{array}{c}\text { Kurtosis } \\
\text { (K) }\end{array}$ & Mode & $\begin{array}{l}\text { Sorting } \\
(\sigma)\end{array}$ & $\begin{array}{l}\text { Skweness } \\
(\phi)\end{array}$ & $\begin{array}{l}\text { Kurtosis } \\
\text { (K) }\end{array}$ \\
\hline 0 & 84.37 & Very Fine Sand & 385.7 & 48.42 & 906.3 & 4.9 & -0.109 & 0.881 & Trimodal & $\begin{array}{l}\text { Very Poorly } \\
\text { Sorted }\end{array}$ & Fine Skewed & Platykurtic \\
\hline 10 & 196.8 & Fine Sand & 236.7 & 802.2 & - & 3.5 & -0.251 & 1094 & Bimodal & Poorly Sorted & Fine Skewed & Mesokurtic \\
\hline 20 & 41.08 & Very Coarse Silt & 54.71 & 145.3 & - & 3.6 & -0.258 & 1057 & Bimodal & Poorly Sorted & Fine Skewed & Mesokurtic \\
\hline 30 & 111.5 & Very Fine Sand & 341.3 & 113.8 & 906.3 & 3.3 & -0.123 & 0.932 & Trimodal & Poorly Sorted & Fine Skewed & Mesokurtic \\
\hline 40 & 162.7 & Fine Sand & 628.4 & 100.7 & - & 3.4 & -0.109 & 0.847 & Bimodal & Poorly Sorted & Fine Skewed & Platykurtic \\
\hline 55 & 153.5 & Fine Sand & 628.4 & 113.8 & - & 3.4 & -0.037 & 0.816 & Bimodal & Poorly Sorted & Symmetrical & Platykurtic \\
\hline 65 & 77.24 & Very Fine Sand & 78.9 & 236.7 & 802.2 & 2.7 & 0.129 & 1221 & Trimodal & Poorly Sorted & Coarse Skewed & Leptokurtic \\
\hline 75 & 232.6 & Fine Sand & 341.3 & 113.8 & - & 2.9 & -0.243 & 0.93 & Bimodal & Poorly Sorted & Fine Skewed & Mesokurtic \\
\hline 85 & 597.5 & Medium Sand & 710 & - & - & 2.1 & -0.641 & 1573 & Unimodal & Poorly Sorted & $\begin{array}{l}\text { Very Fine } \\
\text { Skewed }\end{array}$ & $\begin{array}{c}\text { Very } \\
\text { Leptokurtic }\end{array}$ \\
\hline 95 & 62.44 & Very Coarse Silt & 69.83 & - & - & 2.8 & -0.263 & 1352 & Unimodal & Poorly Sorted & Fine Skewed & Leptokurtic \\
\hline 110 & 76.46 & Very Fine Sand & 89.14 & 209.5 & 628.4 & 3.0 & 0.076 & 1253 & Trimodal & Poorly Sorted & Symmetrical & Leptokurtic \\
\hline 120 & 212.5 & Fine Sand & 628.4 & 113.8 & - & 3.5 & -0.305 & 0.859 & Bimodal & Poorly Sorted & $\begin{array}{l}\text { Very Fine } \\
\text { Skewed }\end{array}$ & Platykurtic \\
\hline 130 & 434.6 & Medium Sand & 710 & 42.86 & - & 3.4 & -0.628 & 0.996 & Bimodal & Poorly Sorted & $\begin{array}{l}\text { Very Fine } \\
\text { Skewed }\end{array}$ & Mesokurtic \\
\hline 140 & 270.1 & Fine Sand & 802.2 & 385.7 & 128.6 & 3.5 & -0.346 & 0.896 & Trimodal & Poorly Sorted & $\begin{array}{l}\text { Very Fine } \\
\text { Skewed }\end{array}$ & Platykurtic \\
\hline 150 & 228.1 & Fine Sand & 710 & 341.3 & 113.8 & 3.6 & -0.296 & 0.798 & Polymodal & Poorly Sorted & Fine Skewed & Platykurtic \\
\hline 165 & 175.7 & Fine Sand & 341.3 & 113.8 & - & 3.4 & -0.231 & 0.959 & Bimodal & Poorly Sorted & Fine Skewed & Mesokurtic \\
\hline 175 & 160.2 & Fine Sand & 385.7 & 209.5 & 100.7 & 3.6 & -0.275 & 0.947 & Polymodal & Poorly Sorted & Fine Skewed & Mesokurtic \\
\hline 185 & 119.7 & Fine Sand & 100.7 & 267.4 & - & 3.0 & 0.051 & 0.952 & Bimodal & Poorly Sorted & Symmetrical & Mesokurtic \\
\hline 195 & 76.86 & Very Fine Sand & 61.81 & 341.3 & - & 3.0 & 0.155 & 1092 & Bimodal & Poorly Sorted & Coarse Skewed & Mesokurtic \\
\hline 205 & 113.3 & Fine Sand & 556.2 & 61.81 & - & 3.6 & 0.014 & 0.742 & Bimodal & Poorly Sorted & Symmetrical & Platykurtic \\
\hline 220 & 111.6 & Very Fine Sand & 100.7 & 267.4 & 628.4 & 3.3 & -0.017 & 0.954 & Trimodal & Poorly Sorted & Symmetrical & Mesokurtic \\
\hline 230 & 36.73 & Very Coarse Silt & 33.57 & - & - & 2.7 & -0.159 & 1165 & Unimodal & Poorly Sorted & Fine Skewed & Leptokurtic \\
\hline 240 & 193.2 & Fine Sand & 906.3 & 267.4 & 100.7 & 3.7 & -0.17 & 0.833 & Trimodal & Poorly Sorted & Fine Skewed & Platykurtic \\
\hline 250 & 467.8 & Fine Sand & 802.2 & 37.93 & - & 3.9 & -0.665 & 0.766 & Bimodal & Poorly Sorted & $\begin{array}{l}\text { Very Fine } \\
\text { Skewed }\end{array}$ & Platykurtic \\
\hline 260 & 92.62 & Very Fine Sand & 100.7 & 267.4 & 556.2 & 3.7 & -0.028 & 0.905 & Trimodal & Poorly Sorted & Symmetrical & Mesokurtic \\
\hline
\end{tabular}


Supplementary material 2 (cont.). Sediment mean grain size (SMGS; $\mu \mathrm{m}$ ) and other textural parameters along the core T1.

\begin{tabular}{|c|c|c|c|c|c|c|c|c|c|c|c|c|}
\hline $\begin{array}{l}\text { Depth } \\
\text { (cm) }\end{array}$ & $\begin{array}{l}\text { SMGS } \\
(\mu \mathrm{m})\end{array}$ & $\begin{array}{c}\text { Grain size } \\
\text { classification }\end{array}$ & $\begin{array}{c}\text { Mode } 1 \\
(\mu \mathrm{m})\end{array}$ & $\begin{array}{c}\text { Mode } 2 \\
(\mu \mathrm{m})\end{array}$ & $\begin{array}{c}\text { Mode } 3 \\
(\mu \mathrm{m})\end{array}$ & $\begin{array}{l}\text { Sorting } \\
(\sigma)\end{array}$ & $\begin{array}{l}\text { Skewness } \\
(\phi)\end{array}$ & $\begin{array}{c}\text { Kurtosis } \\
\text { (K) }\end{array}$ & Mode & $\begin{array}{l}\text { Sorting } \\
(\sigma)\end{array}$ & $\begin{array}{l}\text { Skweness } \\
(\phi)\end{array}$ & $\begin{array}{c}\text { Kurtosis } \\
\text { (K) }\end{array}$ \\
\hline 275 & 65.06 & Very Fine Sand & 37.93 & 802.2 & 209.5 & 4.6 & 0.128 & 0.983 & Trimodal & $\begin{array}{l}\text { Very Poorly } \\
\text { Sorted }\end{array}$ & Coarse Skewed & Mesokurtic \\
\hline 285 & 88.5 & Very Fine Sand & 89.14 & 385.7 & - & 2.1 & 0.074 & 1311 & Bimodal & Poorly Sorted & Symmetrical & Leptokurtic \\
\hline 295 & 180.3 & Fine Sand & 385.7 & 113.8 & 710 & 3.0 & -0.194 & 0.946 & Trimodal & Poorly Sorted & Fine Skewed & Mesokurtic \\
\hline 305 & 109.8 & Fine Sand & 100.7 & 802.2 & 236.7 & 3.4 & 0.117 & 0.966 & Trimodal & Poorly Sorted & Coarse Skewed & Mesokurtic \\
\hline 315 & 107.6 & Very Fine Sand & 100.7 & 302.1 & 710 & 2.9 & 0.119 & 0.962 & Trimodal & Poorly Sorted & Coarse Skewed & Mesokurtic \\
\hline 330 & 119.8 & Very Fine Sand & 100.7 & 710 & 341.3 & 4.4 & -0.112 & 1017 & Trimodal & $\begin{array}{l}\text { Very Poorly } \\
\text { Sorted }\end{array}$ & Fine Skewed & Mesokurtic \\
\hline 340 & 413.2 & Medium Sand & 906.3 & 113.8 & - & 3.7 & -0.536 & 0.784 & Bimodal & Poorly Sorted & $\begin{array}{l}\text { Very Fine } \\
\text { Skewed }\end{array}$ & Platykurtic \\
\hline 350 & 488.7 & Medium Sand & 710 & 113.8 & - & 2.8 & -0.614 & 1037 & Bimodal & Poorly Sorted & $\begin{array}{l}\text { Very Fine } \\
\text { Skewed }\end{array}$ & Mesokurtic \\
\hline 360 & 60.32 & Very Coarse Silt & 54.71 & 556.2 & 236.7 & 4.4 & -0.054 & 1178 & Polymodal & $\begin{array}{l}\text { Very Poorly } \\
\text { Sorted }\end{array}$ & Symmetrical & Leptokurtic \\
\hline 370 & 388.5 & Medium Sand & 802.2 & 128.6 & - & 3.2 & -0.484 & 0.945 & Bimodal & Poorly Sorted & $\begin{array}{l}\text { Very Fine } \\
\text { Skewed }\end{array}$ & Mesokurtic \\
\hline 385 & 98.29 & Very Fine Sand & 100.7 & 267.4 & - & 3.3 & -0.094 & 1017 & Bimodal & Poorly Sorted & Symmetrical & Mesokurtic \\
\hline 395 & 81.98 & Very Fine Sand & 341.3 & 48.42 & 802.2 & 4.7 & -0.031 & 0.913 & Trimodal & $\begin{array}{l}\text { Very Poorly } \\
\text { Sorted }\end{array}$ & Symmetrical & Mesokurtic \\
\hline 405 & 236.6 & Fine Sand & 802.2 & 61.81 & - & 3.5 & -0.241 & 0.679 & Bimodal & Poorly Sorted & Fine Skewed & Platykurtic \\
\hline 415 & 245.3 & Fine Sand & 435.7 & 100.7 & - & 3.1 & -0.297 & 0.792 & Bimodal & Poorly Sorted & Fine Skewed & Platykurtic \\
\hline 425 & 289.5 & Fine Sand & 710 & 61.81 & - & 3.9 & -0.48 & 0.781 & Bimodal & Poorly Sorted & $\begin{array}{l}\text { Very Fine } \\
\text { Skewed }\end{array}$ & Platykurtic \\
\hline 440 & 517.2 & Coarse Sand & 710 & - & - & 2.0 & -0.368 & 2185 & Unimodal & Poorly Sorted & $\begin{array}{l}\text { Very Fine } \\
\text { Skewed }\end{array}$ & $\begin{array}{c}\text { Very } \\
\text { Leptokurtic }\end{array}$ \\
\hline 450 & 128.3 & Fine Sand & 113.8 & 236.7 & 710 & 2.9 & 0.036 & 0.985 & Trimodal & Poorly Sorted & Symmetrical & Mesokurtic \\
\hline 460 & 31.67 & Coarse Silt & 37.93 & 4763 & 236.7 & 4.3 & -0.243 & 1203 & Trimodal & $\begin{array}{l}\text { Very Poorly } \\
\text { Sorted }\end{array}$ & Fine Skewed & Leptokurtic \\
\hline 470 & 133.2 & Fine Sand & 710 & 48.42 & - & 4.0 & -0.073 & 0.776 & Bimodal & Poorly Sorted & Symmetrical & Platykurtic \\
\hline 480 & 42.65 & Very Coarse Silt & 37.93 & 492.3 & 710 & 5.9 & 0.029 & 1227 & Polymodal & $\begin{array}{c}\text { Very Poorly } \\
\text { Sorted } \\
\end{array}$ & Symmetrical & Leptokurtic \\
\hline
\end{tabular}


Supplementary material 3. List of species identified in the study area.

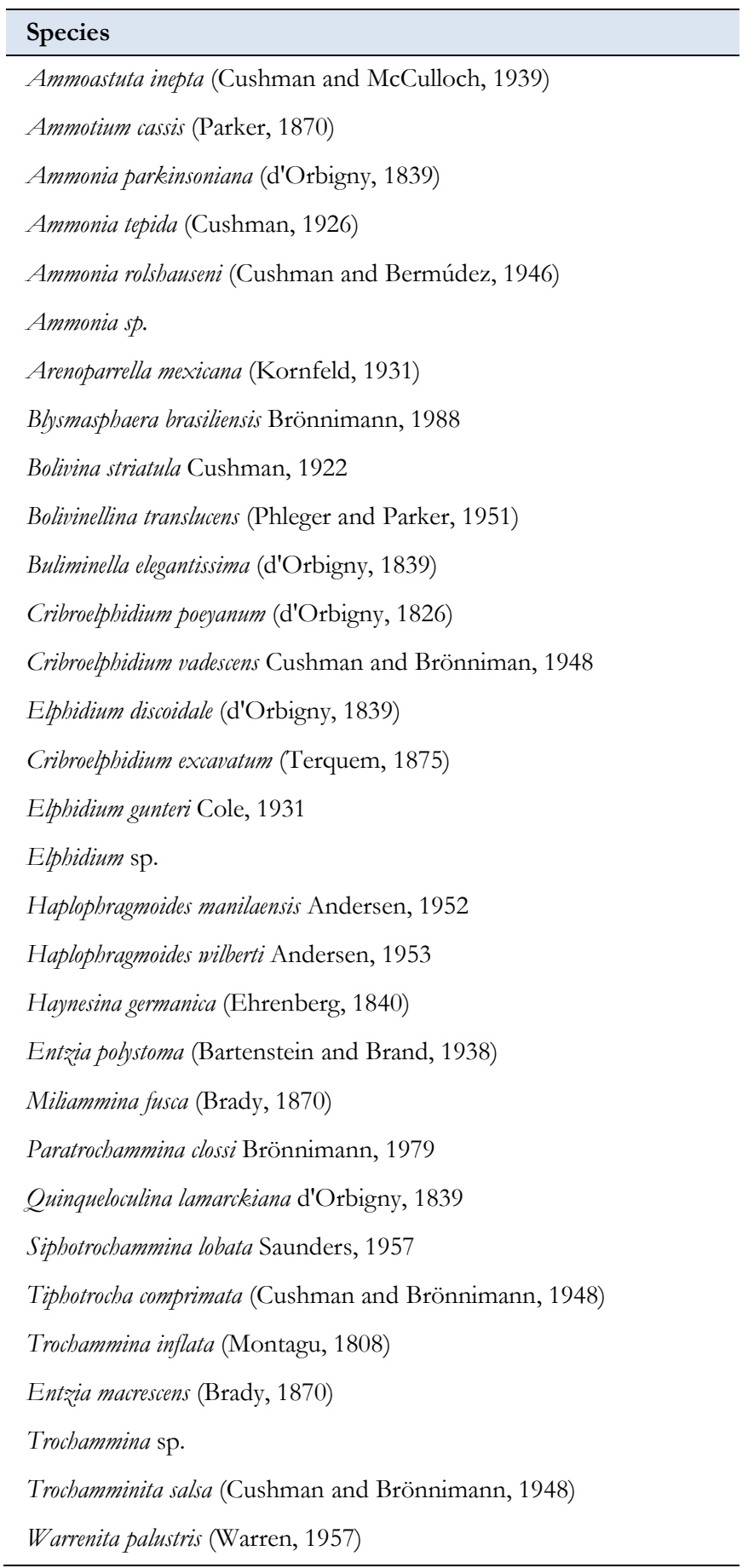


Supplementary material 4a. Species abundance ( $\left.\mathrm{n}^{\circ} / 10 \mathrm{ml}\right)$ in the along the core T1 (at each $10 \mathrm{~cm}$ ). Legend of this table: A. inepta - Ammoastuta inepta; A.cassis Ammotium cassis; A.park. - Ammonia parkinsoniana; A.tep - Ammonia tepida; A.rolsh - Ammonia rolshauseni; Amm. sp.- Ammonia sp.; A.mex - Arenoparrella mexicana; B.brasil Blysmasphaera brasiliensis; B.striat - Bolivina striatula; B.transl - Bolivinellina translucens; B.eleg - Buliminella elegantíssima; C.poey - Cribroelphidium poeyanum; C.vad - Cribroelphidium vadescens; E.disc - Elphidium discoidale; C.excav - Cribroelphidium excavatum; E.gunt - Elphidium gunteri; Elph. sp.; Elphidium sp.; H.manil. - Haplophragmoides manilaensis; H.wilb - Haplophragmoides wilberti; H.germ - Haynesina germanica; E.polyst - Entria polystoma; M.fusca - Miliammina fusca.

\begin{tabular}{|c|c|c|c|c|c|c|c|c|c|c|c|c|c|c|c|c|c|c|c|c|c|c|c|}
\hline Depth (cm) & 0 & 10 & 20 & 30 & 40 & 55 & 65 & 75 & 85 & 95 & 110 & 120 & 130 & 140 & 150 & 165 & 175 & 185 & 195 & 205 & 220 & 230 & 240 \\
\hline Foram D & 136 & 144 & 25 & 0 & 0 & 0 & 107 & 0 & 4 & 2 & 38 & 2 & 0 & 3 & 2 & 96 & 88 & 204 & 261 & 118 & 242 & 218 & 307 \\
\hline SR & 31 & 31 & 31 & 31 & 31 & 31 & 31 & 31 & 31 & 31 & 31 & 31 & 31 & 31 & 31 & 31 & 31 & 31 & 31 & 31 & 31 & 31 & 31 \\
\hline A. inepta & 0 & 0 & 0 & 0 & 0 & 0 & 0 & 0 & 0 & 0 & 1 & 0 & 0 & 0 & 0 & 0 & 1 & 0 & 0 & 0 & 0 & 0 & 0 \\
\hline A.cassis & 0 & 1 & 0 & 0 & 0 & 0 & 0 & 0 & 0 & 0 & 0 & 0 & 0 & 0 & 0 & 0 & 0 & 0 & 0 & 0 & 0 & 0 & 0 \\
\hline A.park. & 0 & 0 & 0 & 0 & 0 & 0 & 0 & 0 & 0 & 0 & 0 & 0 & 0 & 0 & 0 & 3 & 2 & 3 & 62 & 39 & 21 & 36 & 53 \\
\hline A.tep & 0 & 0 & 0 & 0 & 0 & 0 & 0 & 0 & 0 & 0 & 0 & 0 & 0 & 0 & 0 & 43 & 39 & 110 & 55 & 70 & 113 & 122 & 156 \\
\hline A.rolsh & 0 & 0 & 0 & 0 & 0 & 0 & 0 & 0 & 0 & 0 & 0 & 0 & 0 & 0 & 0 & 0 & 0 & 0 & 0 & 0 & 0 & 0 & 0 \\
\hline Amm. sp. & 0 & 0 & 0 & 0 & 0 & 0 & 0 & 0 & 0 & 0 & 0 & 0 & 0 & 0 & 0 & 0 & 0 & 0 & 0 & 0 & 0 & 0 & 0 \\
\hline A.mex & 112 & 61 & 21 & 0 & 0 & 0 & 104 & 0 & 3 & 2 & 25 & 2 & 0 & 1 & 1 & 0 & 4 & 0 & 40 & 0 & 0 & 0 & 1 \\
\hline B.brasil & 0 & 0 & 0 & 0 & 0 & 0 & 0 & 0 & 0 & 0 & 1 & 0 & 0 & 0 & 1 & 0 & 0 & 0 & 0 & 0 & 0 & 0 & 0 \\
\hline B.striat & 0 & 0 & 0 & 0 & 0 & 0 & 0 & 0 & 0 & 0 & 0 & 0 & 0 & 0 & 0 & 0 & 0 & 5 & 7 & 3 & 1 & 6 & 4 \\
\hline B.transl & 0 & 0 & 0 & 0 & 0 & 0 & 0 & 0 & 0 & 0 & 0 & 0 & 0 & 0 & 0 & 1 & 0 & 0 & 0 & 0 & 0 & 0 & 0 \\
\hline B.eleg & 0 & 0 & 0 & 0 & 0 & 0 & 0 & 0 & 0 & 0 & 0 & 0 & 0 & 0 & 0 & 0 & 0 & 12 & 14 & 0 & 0 & 1 & 0 \\
\hline C.poey & 0 & 0 & 0 & 0 & 0 & 0 & 0 & 0 & 0 & 0 & 0 & 0 & 0 & 0 & 0 & 22 & 13 & 12 & 0 & 3 & 15 & 9 & 28 \\
\hline C.vad & 0 & 0 & 0 & 0 & 0 & 0 & 0 & 0 & 0 & 0 & 0 & 0 & 0 & 0 & 0 & 0 & 0 & 0 & 24 & 0 & 33 & 0 & 0 \\
\hline E.disc & 0 & 0 & 0 & 0 & 0 & 0 & 0 & 0 & 0 & 0 & 0 & 0 & 0 & 0 & 0 & 1 & 0 & 0 & 0 & 0 & 0 & 0 & 0 \\
\hline C.excav & 0 & 0 & 0 & 0 & 0 & 0 & 0 & 0 & 0 & 0 & 0 & 0 & 0 & 0 & 0 & 17 & 0 & 14 & 1 & 3 & 43 & 15 & 16 \\
\hline E.gunt & 0 & 0 & 0 & 0 & 0 & 0 & 0 & 0 & 0 & 0 & 0 & 0 & 0 & 0 & 0 & 0 & 7 & 0 & 0 & 0 & 4 & 0 & 17 \\
\hline Elph. sp. & 0 & 0 & 0 & 0 & 0 & 0 & 0 & 0 & 0 & 0 & 0 & 0 & 0 & 0 & 0 & 1 & 9 & 10 & 0 & 0 & 0 & 21 & 4 \\
\hline H.manil. & 2 & 14 & 0 & 0 & 0 & 0 & 0 & 0 & 0 & 0 & 0 & 0 & 0 & 0 & 0 & 0 & 0 & 0 & 0 & 0 & 0 & 0 & 0 \\
\hline H.wilb & 0 & 23 & 0 & 0 & 0 & 0 & 0 & 0 & 0 & 0 & 3 & 0 & 0 & 0 & 0 & 0 & 0 & 0 & 0 & 0 & 0 & 0 & 0 \\
\hline H.germ & 0 & 0 & 0 & 0 & 0 & 0 & 0 & 0 & 0 & 0 & 0 & 0 & 0 & 0 & 0 & 8 & 13 & 35 & 36 & 0 & 12 & 8 & 28 \\
\hline E.polyst & 0 & 0 & 0 & 0 & 0 & 0 & 0 & 0 & 0 & 0 & 1 & 0 & 0 & 0 & 0 & 0 & 0 & 0 & 0 & 0 & 0 & 0 & 0 \\
\hline M. fusca & 0 & 5 & 0 & 0 & 0 & 0 & 0 & 0 & 0 & 0 & 1 & 0 & 0 & 1 & 0 & 0 & 0 & 0 & 0 & 0 & 0 & 0 & 0 \\
\hline
\end{tabular}


Supplementary material 4a (cont.). Species abundance (n. $/ 10 \mathrm{ml}$ ) in the along the core T1 (at each $10 \mathrm{~cm}$ ). Legend of this table: P.clossi - Paratrochammina clossi; Q.lamark - Quinqueloculina lamarckiana; S.lobat - Siphotrochammina lobata; T.comp - Tiphotrocha comprimata; T.infl - Trochammina inflata; E.macr - Entzia macrescens; Troch sp. -

Trochammina sp.; T.salsa - Trochamminita salsa; W.palus - Warrenita palustris.

\begin{tabular}{ccccccccccccccccccccccccc}
\hline Depth (cm) & $\mathbf{0}$ & $\mathbf{1 0}$ & $\mathbf{2 0}$ & $\mathbf{3 0}$ & $\mathbf{4 0}$ & $\mathbf{5 5}$ & $\mathbf{6 5}$ & $\mathbf{7 5}$ & $\mathbf{8 5}$ & $\mathbf{9 5}$ & $\mathbf{1 1 0}$ & $\mathbf{1 2 0}$ & $\mathbf{1 3 0}$ & $\mathbf{1 4 0}$ & $\mathbf{1 5 0}$ & $\mathbf{1 6 5}$ & $\mathbf{1 7 5}$ & $\mathbf{1 8 5}$ & $\mathbf{1 9 5}$ & $\mathbf{2 0 5}$ & $\mathbf{2 2 0}$ & $\mathbf{2 3 0}$ & $\mathbf{2 4 0}$ \\
\hline P.clossi & 0 & 0 & 0 & 0 & 0 & 0 & 0 & 0 & 0 & 0 & 1 & 0 & 0 & 0 & 0 & 0 & 0 & 0 & 0 & 0 & 0 & 0 & 0 \\
Q.lamark & 0 & 0 & 0 & 0 & 0 & 0 & 0 & 0 & 0 & 0 & 0 & 0 & 0 & 1 & 0 & 0 & 0 & 0 & 0 & 0 & 0 & 0 & 0 \\
S.lobat & 0 & 1 & 0 & 0 & 0 & 0 & 1 & 0 & 0 & 0 & 0 & 0 & 0 & 0 & 0 & 0 & 0 & 0 & 0 & 0 & 0 & 0 & 0 \\
T.comp & 0 & 1 & 0 & 0 & 0 & 0 & 0 & 0 & 0 & 0 & 1 & 0 & 0 & 0 & 0 & 0 & 0 & 0 & 0 & 0 & 0 & 0 & 0 \\
T.infl & 20 & 21 & 2 & 0 & 0 & 0 & 0 & 0 & 0 & 0 & 0 & 0 & 0 & 0 & 0 & 0 & 0 & 0 & 10 & 0 & 0 & 0 & 0 \\
E.macr & 2 & 15 & 1 & 0 & 0 & 0 & 0 & 0 & 1 & 0 & 4 & 0 & 0 & 0 & 0 & 0 & 0 & 3 & 10 & 0 & 0 & 0 & 0 \\
Troch sp. & 0 & 1 & 1 & 0 & 0 & 0 & 0 & 0 & 0 & 0 & 0 & 0 & 0 & 0 & 0 & 0 & 0 & 0 & 0 & 0 & 0 & 0 & 0 \\
T.salsa & 0 & 0 & 0 & 0 & 0 & 0 & 2 & 0 & 0 & 0 & 0 & 0 & 0 & 0 & 0 & 0 & 0 & 0 & 2 & 0 & 0 & 0 & 0 \\
W.palus. & 0 & 1 & 0 & 0 & 0 & 0 & 0 & 0 & 0 & 0 & 0 & 0 & 0 & 0 & 0 & 0 & 0 & 0 & 0 & 0 & 0 & 0 & 0 \\
\hline
\end{tabular}


Supplementary material 4b. Species abundance (n. ${ }^{\circ} / 10 \mathrm{ml}$ ) in the along the core T1 (at each $10 \mathrm{~cm}$ ). Legend of this table: A. inepta - Ammoastuta inepta; A.cassis Ammotium cassis; A.park. - Ammonia parkinsoniana; A.tep - Ammonia tepida; A.rolsh - Ammonia rolshauseni; Amm. sp.- Ammonia sp.; A.mex - Arenoparrella mexicana; B.brasil Blysmasphaera brasiliensis; B.striat - Bolivina striatula; B.transl - Bolivinellina translucens; B.eleg - Buliminella elegantissima; C.poey - Cribroelphidium poeyanum; C.vad - Cribroelphidium vadescens; E.disc - Elphidium discoidale; C.excav - Cribroelphidium excavatum; E.gunt - Elphidium gunteri; Elph. sp.; Elphidium sp.; H.manil. - Haplophragmoides manilaensis; H.wilb - Haplophragmoides wilberti; H.germ - Haynesina germanica; E.polyst - Entzia polystoma; M.fusca - Miliammina fusca.

\begin{tabular}{|c|c|c|c|c|c|c|c|c|c|c|c|c|c|c|c|c|c|c|c|c|c|c|}
\hline Depth(cm) & 250 & 260 & 275 & 285 & 295 & 305 & 315 & 330 & 340 & 350 & 360 & 370 & 385 & 395 & 405 & 415 & 425 & 440 & 450 & 460 & 470 & 480 \\
\hline Foram D & 317 & 241 & 315 & 321 & 270 & 325 & 29 & 0 & 70 & 0 & 1 & 0 & 2 & 0 & 1 & 0 & 0 & 0 & 0 & 0 & 0 & 0 \\
\hline SR & 9 & 7 & 8 & 9 & 11 & 8 & 7 & 0 & 8 & 0 & 1 & 0 & 2 & 0 & 1 & 0 & 0 & 0 & 0 & 0 & 0 & 0 \\
\hline Acassis & 0 & 0 & 0 & 0 & 0 & 0 & 0 & 0 & 0 & 0 & 0 & 0 & 0 & 0 & 0 & 0 & 0 & 0 & 0 & 0 & 0 & 0 \\
\hline Apank & 88 & 26 & 27 & 60 & 31 & 70 & 2 & 0 & 0 & 0 & 0 & 0 & 0 & 0 & 0 & 0 & 0 & 0 & 0 & 0 & 0 & 0 \\
\hline A.rolsh & 0 & 0 & 0 & 1 & 0 & 0 & 0 & 0 & 0 & 0 & 0 & 0 & 0 & 0 & 0 & 0 & 0 & 0 & 0 & 0 & 0 & 0 \\
\hline Amm.s. & 15 & 0 & 0 & 0 & 25 & 0 & 0 & 0 & 0 & 0 & 0 & 0 & 0 & 0 & 0 & 0 & 0 & 0 & 0 & 0 & 0 & 0 \\
\hline Amex & 0 & 0 & 0 & 0 & 0 & 2 & 0 & 0 & 0 & 0 & 0 & 0 & 1 & 0 & 1 & 0 & 0 & 0 & 0 & 0 & 0 & 0 \\
\hline B.brasil & 0 & 0 & 0 & 0 & 0 & 0 & 0 & 0 & 0 & 0 & 1 & 0 & 1 & 0 & 0 & 0 & 0 & 0 & 0 & 0 & 0 & 0 \\
\hline Bstriat & 1 & 0 & 0 & 0 & 2 & 4 & 2 & 0 & 4 & 0 & 0 & 0 & 0 & 0 & 0 & 0 & 0 & 0 & 0 & 0 & 0 & 0 \\
\hline Cpay & 22 & 15 & 36 & 37 & 35 & 20 & 1 & 0 & 1 & 0 & 0 & 0 & 0 & 0 & 0 & 0 & 0 & 0 & 0 & 0 & 0 & 0 \\
\hline Cund & 0 & 0 & 3 & 13 & 11 & 0 & 0 & 0 & 0 & 0 & 0 & 0 & 0 & 0 & 0 & 0 & 0 & 0 & 0 & 0 & 0 & 0 \\
\hline Edsc & 5 & 0 & 0 & 2 & 3 & 0 & 0 & 0 & 1 & 0 & 0 & 0 & 0 & 0 & 0 & 0 & 0 & 0 & 0 & 0 & 0 & 0 \\
\hline Cexcay & 18 & 22 & 47 & 72 & 58 & 31 & 9 & 0 & 37 & 0 & 0 & 0 & 0 & 0 & 0 & 0 & 0 & 0 & 0 & 0 & 0 & 0 \\
\hline Egmat & 5 & 2 & 33 & 50 & 21 & 12 & 2 & 0 & 4 & 0 & 0 & 0 & 0 & 0 & 0 & 0 & 0 & 0 & 0 & 0 & 0 & 0 \\
\hline Elph.sp. & 0 & 3 & 14 & 0 & 26 & 0 & 0 & 0 & 0 & 0 & 0 & 0 & 0 & 0 & 0 & 0 & 0 & 0 & 0 & 0 & 0 & 0 \\
\hline H.manil. & 0 & 0 & 0 & 0 & 0 & 0 & 0 & 0 & 0 & 0 & 0 & 0 & 0 & 0 & 0 & 0 & 0 & 0 & 0 & 0 & 0 & 0 \\
\hline Hovilb & 0 & 0 & 0 & 0 & 0 & 0 & 0 & 0 & 0 & 0 & 0 & 0 & 0 & 0 & 0 & 0 & 0 & 0 & 0 & 0 & 0 & 0 \\
\hline Hgam & 10 & 11 & 0 & 9 & 6 & 3 & 0 & 0 & 1 & 0 & 0 & 0 & 0 & 0 & 0 & 0 & 0 & 0 & 0 & 0 & 0 & 0 \\
\hline
\end{tabular}


Supplementary material 4b (cont.). Species abundance $\left(\mathrm{n}^{\circ} / 10 \mathrm{ml}\right)$ in the along the core T1 (at each $\left.10 \mathrm{~cm}\right)$. Legend of this table: P.clossi - Paratrochammina clossi; Q.lamark - Quinqueloculina lamarckiana; S.lobat - Siphotrochammina lobata; T.comp - Tiphotrocha comprimata; T.infl - Trochammina inflata; E.macr - Entria macrescens; Troch sp. - Trochammina sp.; T.salsa - Trochamminita salsa; W.palus - Warrenita palustris.

\begin{tabular}{|c|c|c|c|c|c|c|c|c|c|c|c|c|c|c|c|c|c|c|c|c|c|c|c|c|}
\hline Depth(cm) & 250 & & & 275 & 285 & & 295 & 305 & 315 & 330 & 340 & 350 & 360 & 370 & 385 & 395 & 405 & 415 & 425 & 440 & 450 & 460 & 470 & 480 \\
\hline P.dasivi & 0 & & & 0 & 0 & & 0 & 0 & 0 & 0 & 0 & 0 & 0 & 0 & 0 & 0 & 0 & 0 & 0 & 0 & 0 & 0 & 0 & 0 \\
\hline Qlamank & 0 & & & 0 & 0 & & 0 & 0 & 0 & 0 & 0 & 0 & 0 & 0 & 0 & 0 & 0 & 0 & 0 & 0 & 0 & 0 & 0 & 0 \\
\hline T.omp & 0 & 0 & 0 & 0 & 0 & 0 & 0 & 0 & 0 & 0 & 0 & 0 & 0 & 0 & 0 & 0 & 0 & 0 & 0 & 0 & 0 & 0 & 2 & 45 \\
\hline Tinfl & 0 & 0 & 0 & 0 & 0 & 0 & 0 & 0 & 0 & 0 & 0 & 0 & 0 & 0 & 0 & 0 & 0 & 0 & 0 & 0 & 0 & 0 & 53 & 45 \\
\hline Tradsp. & 0 & 0 & 0 & 0 & 0 & 0 & 0 & 0 & 0 & 0 & 0 & 0 & 0 & 0 & 0 & 0 & 0 & 0 & 0 & 0 & 0 & 0 & 2 & 45 \\
\hline Tsalsa & 0 & 0 & 0 & 0 & 0 & 0 & 0 & 0 & 0 & 0 & 0 & 0 & 0 & 0 & 0 & 0 & 0 & 0 & 0 & 0 & 0 & 0 & 4 & 45 \\
\hline Wpalus. & 0 & 0 & 0 & 0 & 0 & 0 & 0 & 0 & 0 & 0 & 0 & 0 & 0 & 0 & 0 & 0 & 0 & 0 & 0 & 0 & 0 & 0 & 1 & 45 \\
\hline
\end{tabular}


Supplementary material 5. Pearson correlations between selected variables (species abundance and abiotic parameters) in all the core T1 analyzed layers. Significant correlations are signed in red color $(p>0.50)$. Legend: SMGS - sediment mean grain size $(\mu \mathrm{m}) ; 63-125$ - very fine sand fraction (\%); TOC - total organic carbon (\%); Stotal sulfur (\%); $\mathrm{CaCO}_{3}$ - calcium carbonate (\%); SR - species richness ( $\mathrm{n}^{\circ}$ species /sample); F.Dens - foraminifera density ( $\left.\mathrm{n}^{\circ} / 10 \mathrm{ml}\right) ;$ A.park - Ammonia parkinsoniana $\left(\mathrm{n}^{\circ} / 10 \mathrm{ml}\right) ;$ A.tep - Ammonia tepida $\left(\mathrm{n}^{\circ} / 10 \mathrm{ml}\right) ;$ A.mex - Arenoparrella mexicana $\left(\mathrm{n}^{\circ} / 10 \mathrm{ml}\right) ;$ B.striat - Bolivina striatula $\left(\mathrm{n}^{\circ} / 10 \mathrm{ml}\right) ;$ B.elegant - Buliminella elegantissima $\left(\mathrm{n}^{\circ} / 10\right.$ $\mathrm{ml})$; C.poey - Cribroelphidium poevanum $\left(\mathrm{n}^{\circ} / 10 \mathrm{ml}\right)$; C.vad - Cribroelphidium vadescens $\left(\mathrm{n}^{\circ} / 10 \mathrm{ml}\right) ;$ E.disc - Elphidium discoidale $\left(\mathrm{n}^{\circ} / 10 \mathrm{ml}\right) ;$ C.excav - Cribroelphidium excavatum $\left(\mathrm{n}^{\circ} / 10 \mathrm{ml}\right)$; E.gunt - Elphidium gunteri $\left(\mathrm{n}^{\circ} / 10 \mathrm{ml}\right) ;$ Elph. sp. - Elphidium sp. $\left(\mathrm{n}^{\circ} / 10 \mathrm{ml}\right) ;$ H.germ - Haynesina germanica $\left(\mathrm{n}^{\circ} / 10 \mathrm{ml}\right) ;$ T.infla - Trochammina inflata $\left(\mathrm{n}^{\circ} / 10 \mathrm{ml}\right) ;$ E.macr - Entria macrescens $\left(\mathrm{n}^{\mathrm{o}} / 10 \mathrm{ml}\right)$.

\begin{tabular}{|c|c|c|c|c|c|c|c|c|c|c|c|c|c|c|c|c|c|c|c|c|c|}
\hline & SMGS & 63-125 & тос & $\mathrm{s}$ & $\mathrm{CaCO}_{3}$ & SR & F.Dens & A.park & A.tep & A.mex & B.striat & B.elegant & C.poey & C.vad & E.disc & C.excav & E.gunt & Elph sp & H.germ & T.infla & E.macr \\
\hline SMGS & 1.00 & -0.61 & -0.09 & -0.05 & 0.06 & -0.18 & -0.23 & -0.19 & -0.15 & -0.21 & -0.10 & -0.14 & -0.11 & -0.16 & 0.17 & -0.09 & -0.03 & -0.18 & -0.09 & -0.14 & -0.10 \\
\hline 63-125 & -0.61 & 1.00 & -0.06 & -0.04 & 0.01 & 0.35 & 0.35 & 0.26 & 0.27 & 0.17 & 0.23 & 0.22 & 0.23 & 0.27 & -0.01 & 0.27 & 0.22 & 0.13 & 0.24 & 0.02 & 0.11 \\
\hline s & -0.05 & -0.04 & 0.04 & 1.00 & -0.31 & -0.47 & -0.50 & -0.30 & -0.31 & -0.31 & -0.21 & -0.16 & -0.31 & -0.22 & -0.23 & -0.35 & -0.28 & -0.17 & -0.20 & -0.46 & -0.33 \\
\hline $\mathrm{CaCO}_{3}$ & 0.06 & 0.01 & 0.52 & -0.31 & 1.00 & 0.06 & 0.06 & -0.10 & -0.16 & 0.35 & -0.32 & -0.27 & -0.07 & 0.04 & 0.00 & -0.15 & -0.05 & -0.04 & -0.12 & 0.25 & 0.15 \\
\hline SR & -0.18 & 0.35 & -0.22 & -0.47 & 0.06 & 1.00 & 0.96 & 0.69 & 0.77 & 0.35 & 0.58 & 0.38 & 0.70 & 0.40 & 0.38 & 0.71 & 0.57 & 0.48 & 0.67 & 0.28 & 0.39 \\
\hline F.Dens & -0.23 & 0.35 & -0.19 & -0.50 & 0.06 & 0.96 & 1.00 & 0.78 & 0.84 & 0.34 & 0.60 & 0.36 & 0.77 & 0.44 & 0.39 & 0.76 & 0.62 & 0.51 & 0.71 & 0.29 & 0.33 \\
\hline A.park & -0.19 & 0.26 & -0.47 & -0.30 & -0.10 & 0.69 & 0.78 & 1.00 & 0.92 & -0.10 & 0.65 & 0.27 & 0.84 & 0.55 & 0.45 & 0.80 & 0.70 & 0.48 & 0.75 & 0.00 & 0.02 \\
\hline A.tep & -0.15 & 0.27 & -0.51 & -0.31 & -0.16 & 0.77 & 0.84 & 0.92 & 1.00 & -0.17 & 0.70 & 0.40 & 0.92 & 0.45 & 0.42 & 0.89 & 0.71 & 0.60 & 0.83 & -0.07 & 0.00 \\
\hline A.mex & -0.21 & 0.17 & 0.57 & -0.31 & 0.35 & 0.35 & 0.34 & -0.10 & -0.17 & 1.00 & -0.02 & 0.10 & -0.24 & 0.04 & -0.18 & -0.27 & -0.16 & -0.15 & -0.02 & 0.74 & 0.69 \\
\hline B.striat & -0.10 & 0.23 & -0.42 & -0.21 & -0.32 & 0.58 & 0.60 & 0.65 & 0.70 & -0.02 & 1.00 & 0.67 & 0.45 & 0.29 & 0.17 & 0.58 & 0.30 & 0.39 & 0.63 & 0.08 & 0.21 \\
\hline B.elegant & -0.14 & 0.22 & -0.25 & -0.16 & -0.27 & 0.38 & 0.36 & 0.27 & 0.40 & 0.10 & 0.67 & 1.00 & 0.12 & 0.31 & -0.03 & 0.28 & 0.02 & 0.28 & 0.49 & 0.24 & 0.48 \\
\hline C.vad & -0.16 & 0.27 & -0.27 & -0.22 & 0.04 & 0.40 & 0.44 & 0.55 & 0.45 & 0.04 & 0.29 & 0.31 & 0.41 & 1.00 & 0.31 & 0.49 & 0.50 & 0.19 & 0.49 & 0.17 & 0.19 \\
\hline E.disc & 0.17 & -0.01 & -0.32 & -0.23 & 0.00 & 0.38 & 0.39 & 0.45 & 0.42 & -0.18 & 0.17 & -0.03 & 0.53 & 0.31 & 1.00 & 0.56 & 0.52 & 0.18 & 0.38 & -0.10 & -0.12 \\
\hline C.excav & -0.09 & 0.27 & -0.57 & -0.35 & -0.15 & 0.71 & 0.76 & 0.80 & 0.89 & -0.27 & 0.58 & 0.28 & 0.89 & 0.49 & 0.56 & 1.00 & 0.79 & 0.53 & 0.66 & -0.16 & -0.12 \\
\hline E.gunt & -0.03 & 0.22 & -0.42 & -0.28 & -0.05 & 0.57 & 0.62 & 0.70 & 0.71 & -0.16 & 0.30 & 0.02 & 0.82 & 0.50 & 0.52 & 0.79 & 1.00 & 0.47 & 0.50 & -0.15 & -0.20 \\
\hline Elph sp & -0.18 & 0.13 & -0.22 & -0.17 & -0.04 & 0.48 & 0.51 & 0.48 & 0.60 & -0.15 & 0.39 & 0.28 & 0.67 & 0.19 & 0.18 & 0.53 & 0.47 & 1.00 & 0.54 & -0.13 & -0.03 \\
\hline H.germ & -0.09 & 0.24 & -0.32 & -0.20 & -0.12 & 0.67 & 0.71 & 0.75 & 0.83 & -0.02 & 0.63 & 0.49 & 0.75 & 0.49 & 0.38 & 0.66 & 0.50 & 0.54 & 1.00 & 0.05 & 0.19 \\
\hline T.infla & -0.14 & 0.02 & 0.45 & -0.46 & 0.25 & 0.28 & 0.29 & 0.00 & -0.07 & 0.74 & 0.08 & 0.24 & -0.19 & 0.17 & -0.10 & -0.16 & -0.15 & -0.13 & 0.05 & 1.00 & 0.79 \\
\hline E.macr & -0.10 & 0.11 & 0.31 & -0.33 & 0.15 & 0.39 & 0.33 & 0.02 & 0.00 & 0.69 & 0.21 & 0.48 & -0.15 & 0.19 & -0.12 & -0.12 & -0.20 & -0.03 & 0.19 & 0.79 & 1.00 \\
\hline
\end{tabular}


Supplementary material 6. Pearson correlations between selected variables (species abundance and abiotic parameters) in the section $185-340 \mathrm{~cm}$ of core T1 (with calcareous foraminifera and isotopic data). Significant correlations are signed in bold $(p>0.50)$.

\begin{tabular}{|c|c|c|}
\hline Correlations & A.tepida $\delta^{18} \mathbf{O}$ & A.tepida $\delta^{13} \mathrm{C}$ \\
\hline A.tepida $\delta^{18} \mathrm{O}$ & 1.00 & 0.93 \\
\hline A.tepida $\delta^{13} \mathrm{C}$ & 0.93 & 1.00 \\
\hline Total sand fraction (\%) & -0.42 & -0.23 \\
\hline Total fine fraction (\%) & -0.05 & -0.16 \\
\hline Clay fraction (\%) & 0.13 & -0.01 \\
\hline Coarse + medium sand fractions $(\%)$ & -0.40 & -0.23 \\
\hline Total organic carbon $(\%)$ & 0.61 & 0.44 \\
\hline Total sulfur $(\%)$ & 0.10 & 0.02 \\
\hline Calcium carbonate $(\%)$ & -0.33 & -0.16 \\
\hline Species Richness ( $\mathrm{n}^{\circ}$ species / sample) & 0.76 & 0.81 \\
\hline Foraminifera density $\left(\mathrm{n}^{\circ} / 10 \mathrm{ml}\right)$ & 0.36 & 0.40 \\
\hline Ammonia parkinsoniana $\left(\mathrm{n}^{\circ} / 10 \mathrm{ml}\right)$ & 0.32 & 0.28 \\
\hline Ammonia tepida $\left(\mathrm{n}^{\circ} / 10 \mathrm{ml}\right)$ & 0.12 & 0.28 \\
\hline Arenoparrella mexicana $\left(\mathrm{n}^{\circ} / 10 \mathrm{ml}\right)$ & 0.72 & 0.69 \\
\hline Bolivina striatula $\left(\mathrm{n}^{\circ} / 10 \mathrm{ml}\right)$ & 0.66 & 0.58 \\
\hline Buliminella elegantissima $\left(\mathrm{n}^{\circ} / 10 \mathrm{ml}\right)$ & 0.76 & 0.68 \\
\hline Cribroelphidium excavatum $\left(\mathrm{n}^{\circ} / 10 \mathrm{ml}\right)$ & 0.00 & 0.05 \\
\hline Cribroelphidium poeyanum $\left(\mathrm{n}^{\circ} / 10 \mathrm{ml}\right)$ & 0.04 & 0.17 \\
\hline Cribroelphidium vadescens $\left(\mathrm{n}^{\circ} / 10 \mathrm{ml}\right)$ & 0.18 & 0.19 \\
\hline Elphidium discoidale $\left(\mathrm{n}^{\circ} / 10 \mathrm{ml}\right)$ & -0.04 & 0.09 \\
\hline Elphidium gunteri $\left(\mathrm{n}^{\circ} / 10 \mathrm{ml}\right)$ & 0.38 & 0.41 \\
\hline Entzia macrescens $\left(\mathrm{n}^{\circ} / 10 \mathrm{ml}\right)$ & -0.23 & -0.22 \\
\hline Haynesina germanica $\left(\mathrm{n}^{\circ} / 10 \mathrm{ml}\right)$ & 0.24 & 0.16 \\
\hline Trochammina inflata $\left(\mathrm{n}^{\circ} / 10 \mathrm{ml}\right)$ & -0.13 & -0.06 \\
\hline
\end{tabular}

